\title{
Molecular Pathology and Targeted Therapies for Personalized Management of Central Nervous System Germinoma
}

\author{
Cristina Ilcus ${ }^{1, \dagger}{ }^{\dagger}$ Horatiu Silaghi ${ }^{2, *},+\infty$, Carmen Emanuela Georgescu ${ }^{3, \dagger}$, Carmen Georgiu ${ }^{4}$, \\ Anca Ileana Ciurea ${ }^{5} \oplus$, Simona Delia Nicoara ${ }^{6} \oplus$ and Cristina Alina Silaghi ${ }^{3}$ \\ 1 Department of Endocrinology, County Clinical Emergency Hospital Cluj, 3-5 Clinicilor Street, \\ 400006 Cluj-Napoca, Romania; cristina.ilcus@yahoo.com \\ 2 Department of Surgery V, "Iuliu Hațieganu" University of Medicine and Pharmacy Cluj-Napoca, \\ 8 Victor Babes Street, 400012 Cluj-Napoca, Romania \\ 3 Department of Endocrinology, "Iuliu Hațieganu" University of Medicine and Pharmacy Cluj-Napoca, \\ 8 Victor Babes Street, 400012 Cluj-Napoca, Romania; c_e_georgescu@yahoo.com (C.E.G.); \\ alinasilaghi@yahoo.com (C.A.S.) \\ 4 Department of Pathological Anatomy, "Iuliu Hațieganu” University of Medicine and Pharmacy Cluj-Napoca, \\ 8 Victor Babes Street, 400012 Cluj-Napoca, Romania; carmengeorgiu@hotmail.com \\ 5 Department of Radiology, "Iuliu Hațieganu" University of Medicine and Pharmacy Cluj-Napoca, \\ 8 Victor Babes Street, 400012 Cluj-Napoca, Romania; ancaciurea@hotmail.com \\ 6 Department of Ophthalmology, “Iuliu Hațieganu” University of Medicine and Pharmacy, \\ 8 Victor Babes Street, 400012 Cluj-Napoca, Romania; simonanicoara1@gmail.com \\ * Correspondence: horatiu.silaghi@umfcluj.ro \\ + These authors contributed equally.
}

Citation: Ilcus, C.; Silaghi, H.; Georgescu, C.E.; Georgiu, C.; Ciurea, A.I.; Nicoara, S.D.; Silaghi, C.A. Molecular Pathology and Targeted Therapies for Personalized Management of Central Nervous System Germinoma. J. Pers. Med. 2021, 11, 661. https://doi.org/ 10.3390/jpm11070661

Academic Editor: Brona M. Murphy

Received: 6 June 2021

Accepted: 10 July 2021

Published: 14 July 2021

Publisher's Note: MDPI stays neutral with regard to jurisdictional claims in published maps and institutional affiliations.

Copyright: (c) 2021 by the authors. Licensee MDPI, Basel, Switzerland. This article is an open access article distributed under the terms and conditions of the Creative Commons Attribution (CC BY) license (https:// creativecommons.org/licenses/by/ $4.0 /)$.
Abstract: Intracranial germinomas are rare tumours, usually affecting male paediatric patients. They frequently develop in the pineal and suprasellar regions, causing endocrinological disturbances, visual deficits, and increased intracranial pressure. The diagnosis is established on magnetic resonance imaging (MRI), serum and cerebrospinal fluid (CSF) markers, and tumour stereotactic biopsy. Imaging techniques, such as susceptibility-weighted imaging (SWI), T2* (T2-star) gradient echo (GRE) or arterial spin labelling based perfusion-weighted MRI (ASL-PWI) facilitate the diagnosis. Germinomas are highly radiosensitive tumours, with survival rates $>90 \%$ in the context of chemoradiotherapy. However, patients with resistant disease have limited therapeutic options and poor survival. The aim of this review is to highlight the genetic, epigenetic, and immunologic features, which could provide the basis for targeted therapy. Intracranial germinomas present genetic and epigenetic alterations (chromosomal aberrations, KIT, MAPK and PI3K pathways mutations, DNA hypomethylation, miRNA dysregulation) that may represent targets for therapy. Tyrosine kinase and $m T O R$ inhibitors warrant further investigation in these cases. Immune markers, PD-1 (programmed cell death protein 1) and PD-L1 (programmed death-ligand 1), are expressed in germinomas, representing potential targets for immune checkpoint inhibitors. Resistant cases should benefit from a personalized management: genetic and immunological testing and enrolment in trials evaluating targeted therapies in intracranial germinomas.

Keywords: CNS germinoma; KIT; RAS; MAPK; miRNAs; radiotherapy; chemotherapy; personalized targeted therapy

\section{Introduction}

Intracranial germ cell tumours (ICGCT) are rare tumours that primarily affect children and adolescents, with a male predominance, accounting for 3.6\% of brain tumours in Western Europe and reaching a higher incidence of $15.4 \%$ in Japan [1-3]. A comparative study between Japanese and American populations regarding ICGCT revealed a different distribution of the tumours. More cases of basal ganglia involvement were present in the Japanese, whereas more bifocal (synchronous pineal and suprasellar) locations in western 
society, suggesting the presence of genetic or environmental factors, thus, contributing to the phenotypic diversity [4]. According to the WHO classification of the central nervous system (CNS) tumours, the germ cell tumours group, composed of germinoma, represents the most common histological type $(60 \%)$, followed by mixed germ cell tumours $(17.4 \%)$, teratoma $(15.7 \%)$, yolk sac tumour $(4.2 \%)$, choriocarcinoma $(1.6 \%)$, and embryonal carcinoma (1.1\%) [5]. According to Matsutani et al., pure germinoma and mature teratoma have a good prognosis, but other histological types may result in unfavourable prognosis. Intermediate prognosis corresponds to germinoma with syncytiotrophoblastic giant cell [STGC], immature teratoma, teratoma with malignant transformation and mixed tumours composed mainly of germinoma or teratoma, whereas poor prognosis is found in choriocarcinoma, yolk sac tumour, embryonal carcinoma, as well as in mixed tumours composed mainly of choriocarcinoma, yolk sac tumour, or embryonal carcinoma [6,7].

Germinomas usually develop in the midline areas of the brain, most often in the pineal gland (50\% of the pineal tumours are germinomas) and the suprasellar region [8]. In approximately $5-10 \%$ of the cases, the tumour is ectopically situated (in other areas than neurohypophysial or pineal sites), including the basal ganglia, thalamus, corpus callosum, cerebellum, septum pellucidum, temporal lobe, and the spinal cord [9-13]. Suprasellar germinomas are associated with female patients ( $<15$ years old), while pineal germinomas with male patients ( $>15$ years) [14]. In rare cases, germinomas have been described to occur later in life. Several reports mention the diagnosis in the sixth or seventh decade of life, outlining the fact that germinoma should be included as a differential diagnosis even in the elderly [15-19]. Germinomas can also be present as synchronous lesions in the pineal region and hypothalamo-neurohypophyseal axis, also referred to as "bifocal germinomas", with an incidence ranging from to $6 \%$ to $26 \%$ and even as high as $41 \%$ in some studies [20-24]. Metastatic germinomas caused by the dissemination of tumour cells through the cerebrospinal fluid are reported in approximately $4.5 \%$ of the cases, usually after a mean period of 6-7 years after the initial tumour diagnosis $[25,26]$. According to the literature, the most common type of metastasis is spinal "drop metastasis" (32.5\%), followed by ventricular dissemination (30\%), and to a lesser extent, the suprasellar region, corpus callosum, subarachnoid space [26-28]. Concomitant metastases to the ventriculoperitoneal shunt can appear in $20 \%$ of the cases [26].

\section{Clinical Presentation}

Tumours of the pineal gland obstruct the posterior wall of the third ventricle and of the aqueduct of Sylvius, resulting in acute hydrocephalus with headaches, nausea, projectile vomiting, papilledema, and lethargy. Generally, a $2 \mathrm{~cm}$ pineal tumour can cause obstructive hydrocephalus [29]. When the tumour grows, it has a compressive effect on the nerve pathway connecting the cortex to the oculomotor nuclei and the superior colliculi, resulting in Parinaud's syndrome: upward gaze palsy, pupillary reflex dysfunction, and convergence-retraction nystagmus [30]. In comparison with other types of pineal tumours, upward gaze palsy seems to be more frequently encountered in pure germinomas (90\%), as a consequence to the mesencephalic dysfunction caused by the germinoma's progression pattern [31]. In cases of pituitary germinoma, visual disturbances can result from optic chiasma compression or perioptic meningeal seeding [32].

Germinomas developed in the suprasellar region or anterior third ventricle may be presented with endocrinopathy at the diagnosis (diabetes insipidus, delayed growth or gonadal function, precocious puberty, menstrual irregularities, visual field/acuity deficits). Neurohypophyseal axis dysfunction may also appear as an adverse effect of the radiotherapy treatment [21,30,33-35]. Diabetes insipidus (DI) is the most common symptom associated with germinomas occurring in the hypothalamic-neurohypophysial region, followed by visual deficits, hypopituitarism, and increased intracranial pressure [36]. Diabetes insipidus seems to be a reliable predictor of tumoral invasion of the hypothalamus and third ventricle even in the absence of MRI evidence of suprasellar and third ventricle disease [37-39]. GH (growth hormone) deficiency and hypogonadism are the most frequent 
endocrine insufficiencies (89-95\% of cases), followed by hypothyroidism and hypocortisolaemia, in approximately $50 \%$ of patients [40]. Boys with intracerebral germ tumours can develop precocious puberty (isosexual pseudoprecocity) because of beta-human chorionic gonadotropin ( $\beta-\mathrm{hCG}$ ) secretion of the syncytiotrophoblasts component of the tumour, which stimulates Leydig cells, with subsequent production of testosterone [41,42].

Patients with basal ganglia/thalamus germinoma often develop hemiparesis, headache, ataxia, cognitive impairment, and mental status alterations, though the severity of clinical picture does not seem to correlate with the tumour size $[43,44]$. Cases of optic nerve germinoma, although rare, present with progressive visual deficits, followed by endocrine dysfunction (most often DI), symptoms that may be inconsistent with the MRI findings, causing a delay in diagnosis [45].

A retrospective study on 49 children diagnosed with pure germinomas reported visual impairments as the most common symptom ( $47.9 \%)$, followed by motor dysfunctions $(40.8 \%)$, frequently including focal or general weakness, hemiparesis, facial palsy. Patients presenting endocrinological symptoms had a significant delay in diagnosis [39]. Approximately one-third of the patients have prolonged symptomatology (>6 months) before the diagnosis, these cases being associated with a higher risk of metastatic disease [46]. A summary of the clinical presentation is shown in Table 1.

Table 1. Clinical presentation.

\begin{tabular}{ccc}
\hline Neurologic Symptoms & Endocrine Symptoms & Ophthalmologic Symptoms \\
\hline headaches & diabetes insipidus & Parinaud's syndrome \\
nausea & GH insufficiency & visual field deficits \\
projectile vomiting & hypogonadism & acuity deficits \\
papilledema & secondary hypothyroidism & \\
lethargy & hypocortisolaemia (secondary \\
hemiparesis & adrenal insufficiency) \\
ataxia & menstrual irregularities \\
& precocious puberty \\
\hline
\end{tabular}

Abbreviations: GH: growth hormone.

\section{Diagnosis}

\subsection{Biological Markers}

Different biomarkers have been studied in order to establish the optimum diagnosis. A relative correlation between serum and cerebrospinal fluid (CSF) biomarkers and the tumour's histological category was set. Alpha-fetoprotein (AFP) is elevated in embryonal carcinomas and teratomas, whereas choriocarcinomas and germinomas secrete $\beta$-hCG $[47,48]$. However, germinomas have an inconsistent secretion of $\beta$-hCG $[49,50]$. There is no clear cut-off for hCG levels to distinguish germinomas from mixed germ tumours, but it is considered that pure germinomas produce no or mild levels of CSF $\beta$-hCG $(<50 \mathrm{mUI} / \mathrm{mL})$, in the latter cases being classified as high risk and requiring a more aggressive chemotherapy regimen $[37,51]$. A study conducted on 80 germ cell tumours revealed a sensitivity of $78.9 \%$ and a specificity of $96.6 \%$ for CSF tumour markers (with a cut-off of $50 \mathrm{IU} / \mathrm{L}$ for $\mathrm{B}-\mathrm{HCG}$ and $25 \mathrm{ng} / \mathrm{mL}$ for AFP). Marker positive germinomas, as well as marker negative NGGCT have been reported [52].

Other biomarkers associated with germinomas include elevated lactate dehydrogenase (LDH) and placental alkaline phosphatase (PLAP). These biomarkers, in combination with the radiological finding of a pineal mass, could provide a high suspicion of the histological subtype, especially in cases of heterogeneous tumours, and may represent a way of monitoring the treatment response [53]. Aihara et al. discovered that the CSF PLAP level is a specific marker for pure germinomas, which can provide a reliable diagnosis of intracranial germinoma, in the absence of a histopathological examination [54]. However, Chiba et al. propose that CSF PLAP levels, with a cut-off value of $8 \mathrm{pg} / \mathrm{mL}$, also correlate 
with the germinoma component in the context of mixed GCT [55]. The diagnostic algorithm of CNS germinomas, including the main serum/CSF biomarkers, is shown in Figure 1.

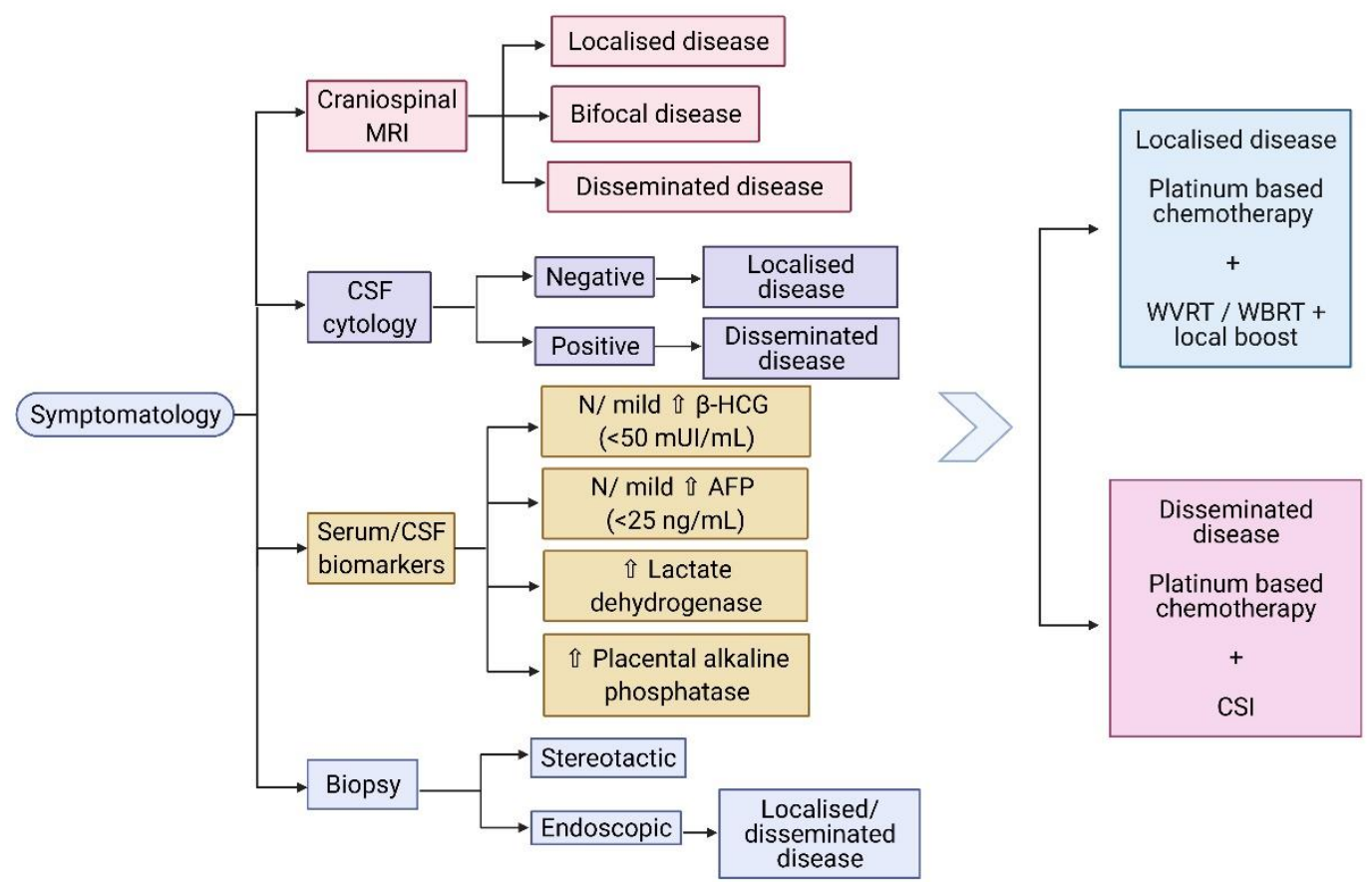

Figure 1. (Created with BioRender.com) Diagnostic algorithm of CNS germinomas. Abbreviations: MRI: magnetic resonance imaging; CSF: cerebrospinal fluid; $\beta$-HCG: beta- human chorionic gonadotropin; AFP: alpha fetoprotein; N: normal; WVRT: whole ventricular radiotherapy; WBRT: whole brain radiotherapy; CSI: craniospinal irradiation.

\subsection{Radiological Characteristics}

On standard MRI, germinomas appear as heterogeneous tumours in T1/T2-weighted imaging, in $40 \%$ of the cases, and the uptake of the gadolinium can be either homogeneous $(47 \%)$ or heterogeneous (53\%) [56]. Relevant images of a pure pineal germinoma are shown in Figure 2.

Multiple imaging studies have been conducted to provide a better characterization of germinomas. For example, Inoue et al. showed that $90 \%$ of the patients with pineal germinomas presented a cardioid-shape tumour image on the axial MRI views, due to its progression pattern on both sides of the third ventricle, concluding that this was a specific aspect for pure pineal germinoma [31]. Awa et al. described two significant features differentiating pineal germinomas from NGGCT: peritumoural edema thicker than $5 \mathrm{~mm}$ (peritumoural area with T2 hyperintensity) and bithalamic extension [57]. T2* (T2-star) sequence is generally used to obtain a better characterization of intratumoural/intraventricular/cerebral microhaemorrhage, iron deposits, and calcifications [58]. Susceptibility-weighted imaging (SWI) or T2* gradient echo (GRE) technique can be used for better differentiation between pure germinoma and NGGCT in the pineal region: $93 \%$ of the germinomas present iso- or hyperintensity, whereas NGGCT are hypointense compared to the healthy brain [56]. Another imaging technique, such as the arterial spin labelling based perfusion-weighted MRI (ASL-PWI) could be used in differentiating germinomas from NGGCT, based on lower values of relative tumour blood flow encountered in germinomas [59]. Calcification can be present in both germinomatous and non-germinomatous pineal tumours [56].

Suprasellar germinomas seem to develop from the tuber cinereum and median eminence, infiltrating the infundibulum [60]. Therefore, an isolated thickened pituitary stalk may be the first radiological appearance of a hypothalamo-hypophyseal germinoma [61,62]. However, they have a delay in diagnosis of a median of 1.4 years, due to insidious onset 
of symptomatology and MRI findings, often suggestive of inflammation (lymphocytic hypophysitis), pituitary adenomas, and secondary neoplasms, with radiological appearance similar to germinomas [63-65]. Nonetheless, GCT represent $66.7 \%$ of widened pituitary stalk causes in paediatric population, whereas germinomas represent the second etiology $(21-31 \%)$ of enlarged pituitary stalk in adults $[62,66]$. Cases of diabetes insipidus followed by the occurrence of germinoma during the MRI follow-up have been described, highlighting the importance of imaging re-examination or endoscopic biopsy (with higher sensitivity compared to imaging studies) [38,61]. Usually, pituitary stalk infiltration is reversible following adequate treatment [60].

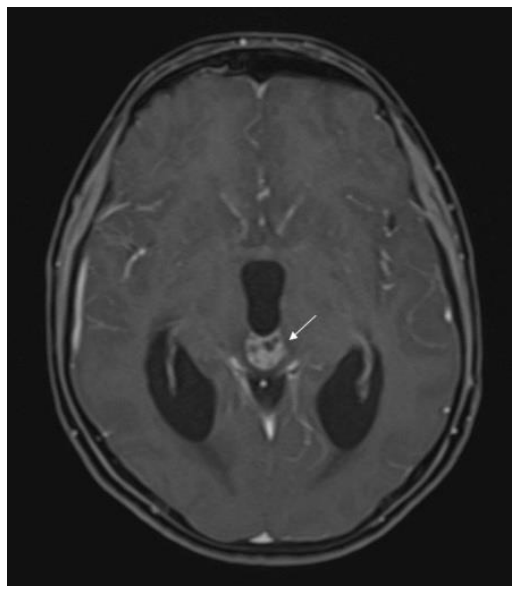

(a)

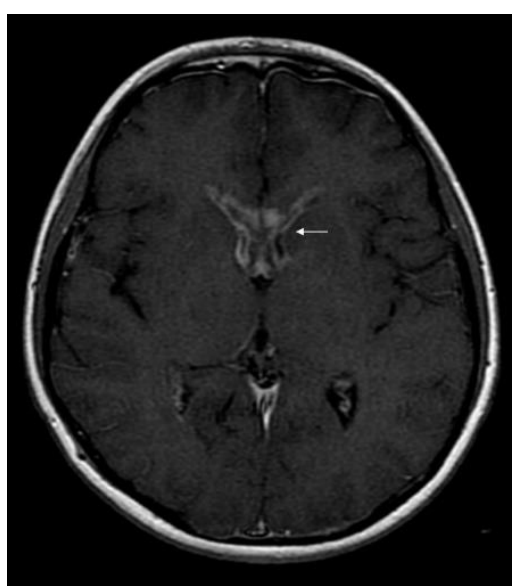

(c)

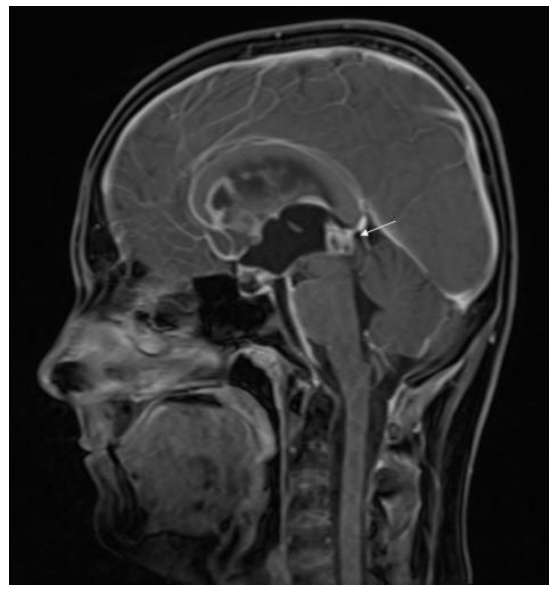

(b)

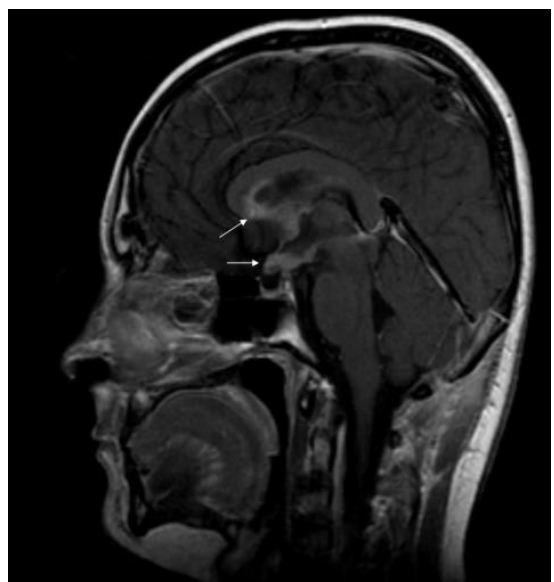

(d)

Figure 2. MRI features of intracranial germinoma in a teenage patient: (a) pineal germinoma: heterogeneous contrast enhancement on axial gadolinium-enhanced T1-weighted image, with a tendency to cardioid shape; (b) pineal germinoma: heterogeneous contrast enhancement on sagittal gadolinium-enhanced T1-weighted image; (c) postoperative disseminated disease: bilateral nodular enhancement of anterior horns of the lateral ventricles on axial gadolinium-enhanced T1-weighted image; (d) postoperative disseminated disease: nodular enhancement of the hypothalamus, optic chiasm, mammillary bodies, and corpus callosum on sagittal gadolinium-enhanced T1-weighted image.

Basal ganglia and thalamus germinomas may present variable neuroimaging features (cystic lesion, peritumoural oedema, calcification, intratumoural haemorrhage, contrast enhancement, ipsilateral cerebral atrophy) that may impede reaching the correct diagnosis. Nonetheless, ipsilateral hemiatrophy seems to be a characteristic feature of basal ganglia and thalamus germinomas, which may differentiate them from other tumour types [44]. 
Surprisingly, the number of lesions detected on the MRI does not represent a poor prognosis factor and does not correlate with the overall survival in the setting of an appropriate treatment protocol [67].

\subsection{Biopsy}

In the management of germinomas, most studies recommend stereotactic biopsy for a definite diagnosis. Balossier et al. have shown that the histopathological diagnosis for pineal biopsies is more accurate with stereotactic procedures than with endoscopic procedures (93.7\% vs. $81.1 \%$ ) [68]. However, several studies emphasized the importance of endoscopic diagnosis, since in patients with pineal germinoma and DI, metastatic lesions to the third ventricular floor are more frequently identified by direct endoscopy than initially diagnosed by MRI $[37,38]$. Accordingly, biopsy-diagnosed pineal germinoma in DI patients should be classified as disseminated disease, even in the absence of MRI evidence [38]. Still, a retrospective multicentre study evaluated the necessity of performing biopsy in patients with bifocal tumour, diabetes insipidus, and negative tumour markers. The study included 91 patients with available histologic diagnosis, of which $92 \%$ were pure germinomas and germinomas with syncytiotrophoblastic giant cells, concluding that a tumour biopsy is recommended to ensure the proper diagnosis [69]. Another retrospective study revealed that in cases of pituitary germinoma suspected on MRI, the biopsy can reveal another pathology in $22 \%$ of the tumours [70]. Moreover, a fairly recent technique that combines endoscopic biopsy with endoscopic ventriculostomy, using a single trajectory, is considered safe and could become an alternative for the dual procedure in pineal germinomas [71].

\subsection{Histological Diagnosis}

Macroscopically, germinomas are solid, soft, grey-white, homogenous tumours; however, they can rarely present areas of haemorrhage, necrosis, or cystic components. They can be variably encapsulated or poorly circumscribed and infiltrative. Microscopically, they consist of large primordial germ cells (undifferentiated cells), with clear, abundant PAS+ cytoplasm, large, round nuclei, and prominent nucleoli; occasionally syncytiotrophoblastic giant cells may be present [72]. The cells have high mitotic activity and are organized in sheets, lobules, or nests patterns, separated by fibrovascular septae filled with lymphocytic infiltrates. Occasionally, the lymphoplasmacellular reaction is so robust that the granulomatous inflammation can obscure the tumour cells [5]. Therefore, a characteristic histopathological feature of germinoma is the "two-cell pattern": a massive immune cell population, with a high lymphocytic predominance, dispersed between tumour cells [73].

Immunohistochemistry (IHC) is further used to provide the histological diagnosis. The membrane immunoreactivity for C-kit (transmembrane protein with tyrosine kinase activity), CD30 (tumour necrosis factor receptor), and D2-40 (podoplanin) aid in differentiating germinomas from embryonal carcinoma and yolk sac tumours [5]. The nucleus is usually reactive for OCT 3/4 (octamer binding transcription factor 3/4), SALL4 (sal-like protein 4), UTF1 (undifferentiated embryonic cell transcription factor 1), NANOG (transcription factor in embryonic stem cells), and ESRG (embryonic stem cell-related gene protein), whereas ribosomes are positive for LIN28 (RNA-binding protein LIN28) [74,75]. Although PLAP is a distinctive marker of primordial cells, its expression is less consistent, being detected in $82 \%$ of germinomas. On the other hand, C-kit and OCT $3 / 4$ are more sensible, with $100 \%$ staining among germinoma cells. When the germinoma also contains a syncytiotrophoblastic component, these cells are positive for hCG, human placental lactogen (HPL), CD 30, and CK AE1/3 (cytokeratin AE1/3) [72]. A summary of IHC staining and representative histological images from intracranial germinomas are shown in Table 2 and Figures 3 and 4 . 
Table 2. Immunohistochemical staining in pure germinomas and germinomas with STGC.

\begin{tabular}{cccc}
\hline Staining & Location & Germinoma Cells & Syncytiotrophoblastic Cells \\
\hline PLAP & Cytoplasm & + & - \\
C-kit & Membrane & + & - \\
OCT 3/4 & Nucleus & + & - \\
HCG & Cytoplasm & - & - \\
AFP & Cytoplasm & - & + \\
CD30 & Membrane & - & + \\
CK AE1/3 & Cytoplasm & - & - \\
D2-40 & Membrane & + & - \\
LIN28 & Ribosomes & + & - \\
HPL & Cytoplasm & - & - \\
NANOG & Nucleus & + & - \\
ESRG & Nucleus & + & - \\
UTF1 & Nucleus & + & + \\
SALL4 & Nucleus & + & - \\
\hline
\end{tabular}

Abbreviations: STGC: syncytiotrophoblastic giant cells; PLAP: placental alkaline phosphatase; C-kit: transmembrane protein with tyrosine kinase activity (or CD117); OCT 3/4: octamer binding transcription factor 3/4; HCG: human chorionic gonadotropin; AFP: alpha fetoprotein; CD30: tumour necrosis factor receptor; CK AE1/3: cytokeratin AE1/3; D2-40: podoplanin; LIN28: RNA-binding protein LIN28; HPL: human placental lactogen; NANOG: transcription factor in embryonic stem cells; ESRG: embryonic stem cell-related gene protein; UTF1: undifferentiated embryonic cell transcription factor 1; SALL4: sal-like protein 4.

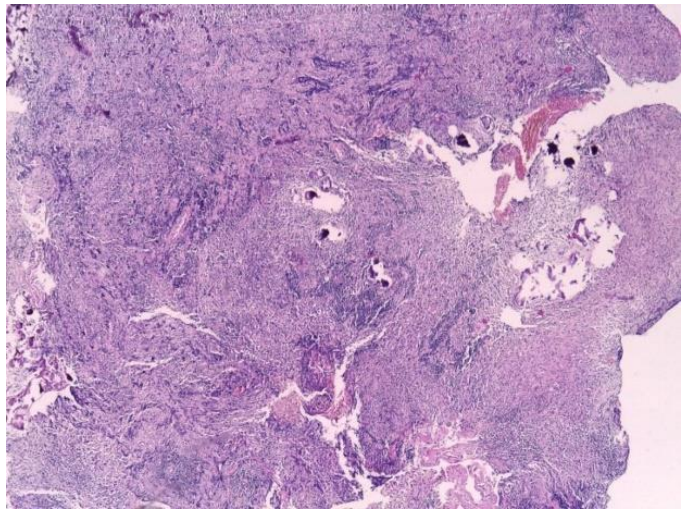

(a)

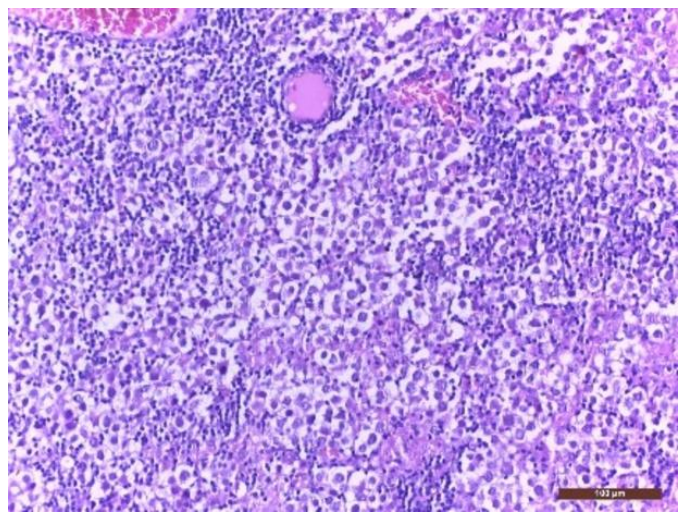

(c)

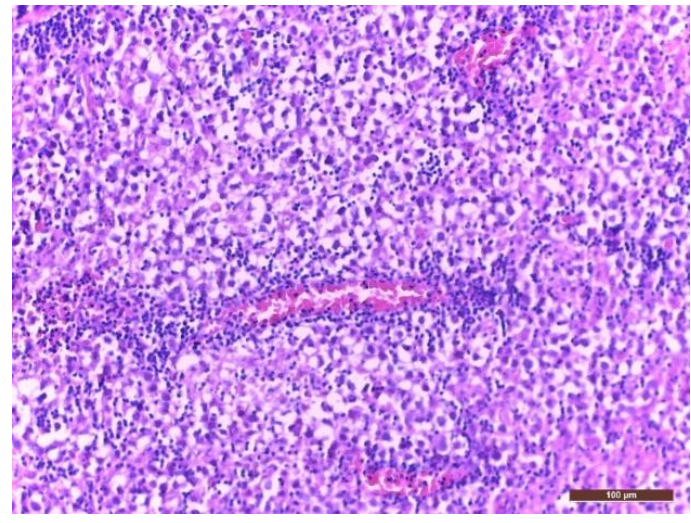

(b)

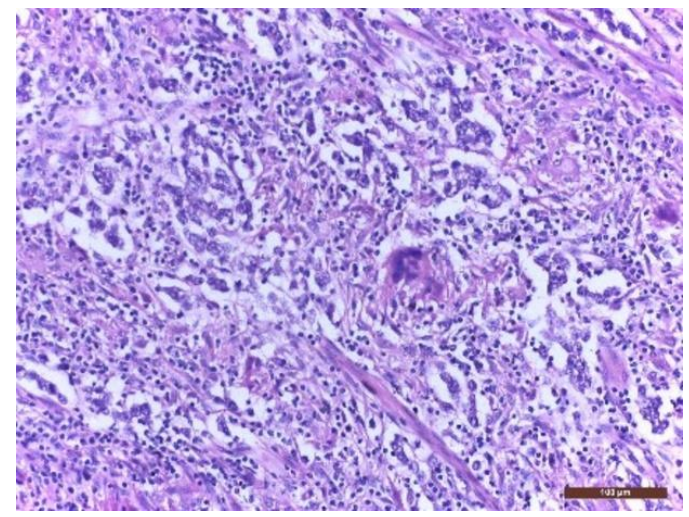

(d)

Figure 3. Microscopic images of extragonadal germinomas are identical with those of their gonadal counterpart: (a) pineal gland, with multiple small basophil psammoma bodies, infiltrated by a germinoma; (b) tumour proliferation with fine vascular network; (c) sheets of large germinoma cells, with pale cytoplasm, well defined cell membranes, large round central nuclei, and fibrous septae heavily infiltrated by lymphocytes; (d) an isolated multinucleated syncytiotrophoblast close to the centre of the image; (hematoxylin eosin staining; (a) $40 \times$ and (b-d) $200 \times$ ). 


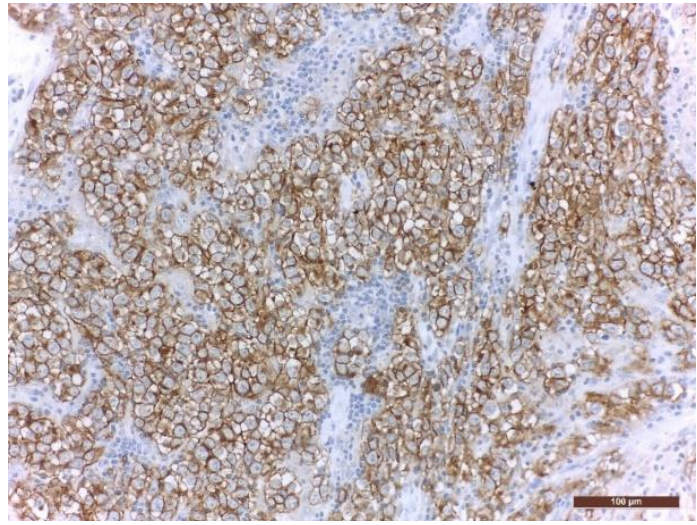

(a)

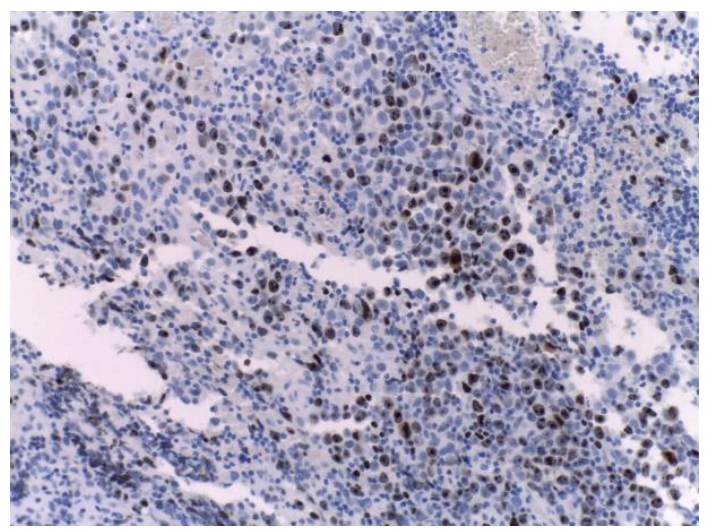

(c)

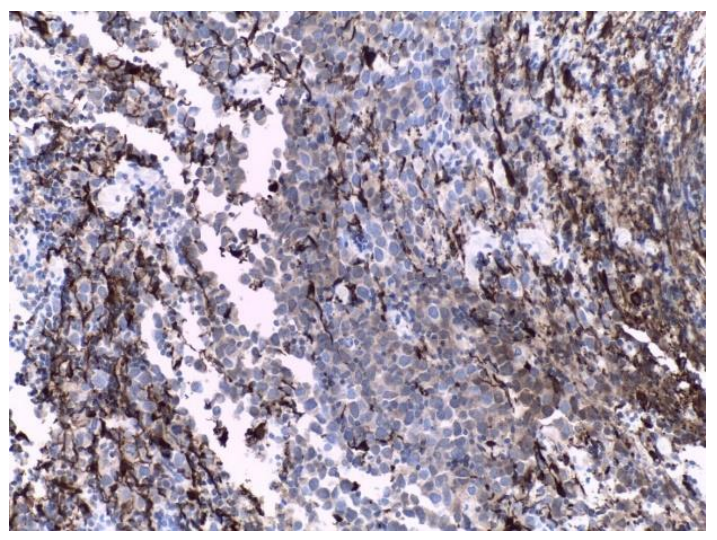

(e)

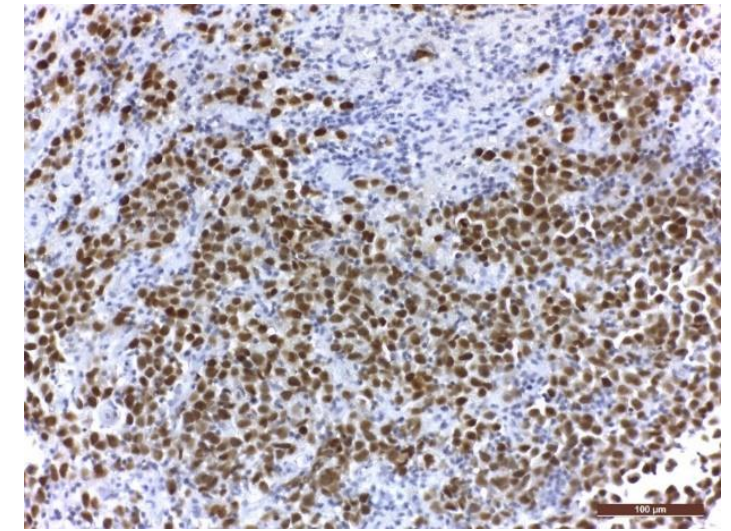

(b)

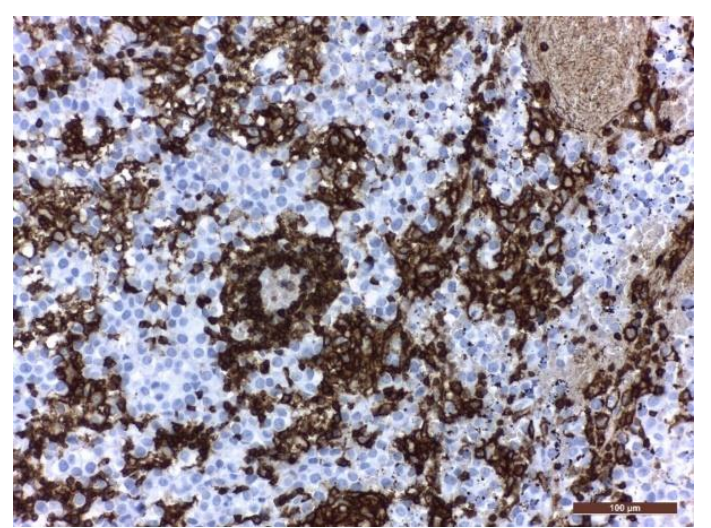

(d)

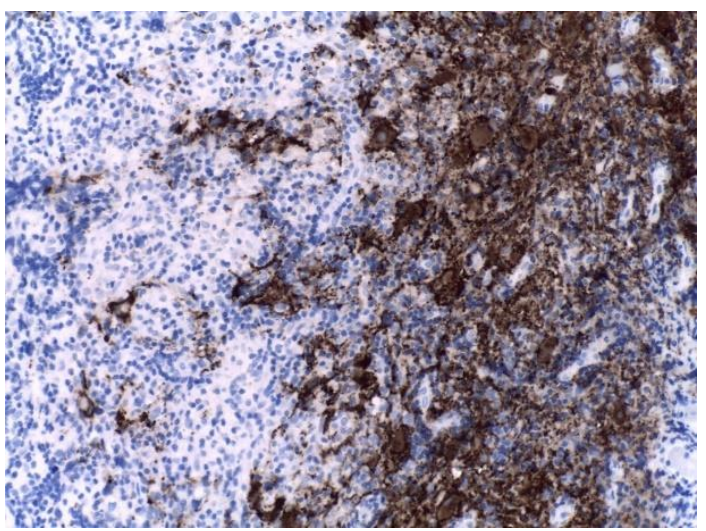

(f)

Figure 4. Immunohistochemical staining in extragonadal germinomas: (a) intense membranous and less intense cytoplasmic c-Kit/CD117 expression; (b) intense nuclear and less intense cytoplasmic OCT3/4 expression; (c) high Ki67 nuclear expression; (d) intense expression of leukocyte common antigen LCA/CD45 in stromal lymphocytes; (e) GFAP expression in glial pineal stromal cells in a case of pineal germinoma; (f) synaptophysin expression in the pinealocytes of a pineal germinoma; $(200 \times)$.

\section{Staging}

Though there are no standard staging criteria for germinomas, a modified Chang staging system is usually used, based on aspect imaging and serum/CSF markers. Localized disease on MRI (no evidence of metastasis) and negative CSF cytology are classified 
as M0, while intracranial/spinal metastasis or positive cytology classify the tumour as disseminated disease $\mathrm{M}+$. Bifocal disease is defined by synchronous pineal and pituitary tumours [76]. Accordingly, an M1 stage presumes positive CSF cytology for tumour cells, and an M2 metastatic germinoma is defined by intracranial nodular seeding (except bifocal disease). The presence of spinal metastases includes the patient in the M3 stage and metastases outside CNS in the M4 stage [77].

\section{Genetic Approach}

Germinomas have immunohistochemical and molecular alterations similar to testicular seminoma, suggesting a common pathogenesis. One theory regarding the origin of germinomas postulates that these tumours develop from primordial germ cells (PGCs) that mismigrated in the midline structures during early embryogenesis. This hypothesis is sustained by the global hypomethylation of germinoma cells, an epigenetic hallmark of PGCs, and by the presence of specific germ cells markers (c-Kit, Oct-3/4, and Nanog). Another theory proposes that germinomas arise from a pluripotent braincell, via KIT gene mutations [73]. There is little molecular data regarding germinoma's development, considering the low incidence of this type of a tumour. Although rare, several familial cases of intracranial germinomas have been described, prompting further genetic studies regarding their tumourigenesis mechanism [78-81]. Fukushima et al. proposed that MAPK and/or PI3K pathway alterations, DNA hypomethylation, and chromosomal abnormalities represent a triad involved in the pathogenesis of pure germinomas [82].

A characteristic feature of germinomas that differentiates them from other ICGCT involves the methylation profile, germinomas presenting DNA hypomethylation, an acknowledged cause of genomic instability [82]. DNA methylation is a process normally involved in the epigenetic reprogramming of the germline during development, and, therefore, aberrant methylation patterns may have a significant role in the aetiology of germ cell tumours [83]. In a cohort of 54 germinomas, hypomethylation and KIT staining by immunohistochemistry were detected in $100 \%$ of the cases, underlining the resemblance to primordial germ cells [14]. Moreover, patients with chromosomal abnormalities (Down's and Klinefelter syndrome) have been reported to develop CNS germinomas [84,85]. Chromosomal gains and losses are frequently encountered in germinomas (as presented in Table 3) $[14,80,86,87]$. Chromosomal aberrations such as gain of $2 q$ and $8 q$ and loss of $5 q$, $9 p / q, 13 q$, and $15 q$ are associated with a worse prognosis [7]. Wang et al. hypothesize that meiosis errors are involved in the pathogenesis of germinomas since $90 \%$ of the cases present chromosomal instability [87].

The most frequent genes involved in the pathogenesis of these tumours are the KIT and $R A S$ genes, encountered in up to $40 \%$ and respectively $34.6 \%$ of germinomas (Table 4 ). Interestingly, KIT and RAS mutations are described as mutually exclusive in $97-100 \%$ of cases $[14,86-88]$.

Table 3. Summary of basal genetic information in CNS germinomas.

\begin{tabular}{cc}
\hline Genetic Alteration & Genes/Chromosomes; Comments \\
\hline DNA hypomethylation & Similarity to primordial cells; genomic instability \\
\hline Chromosomal aberrations & $1 \mathrm{q}(56.7-65 \%), 2 \mathrm{q}, 4 \mathrm{q}, 7(59 \%), 8(67 \%), 11 \mathrm{p}, 12 \mathrm{p}(36.4-82 \%), 21 \mathrm{q}(63.6-76 \%)$ and \\
Gains & $\times(53.5-72.7 \%)$ \\
Losses & $1 \mathrm{p} / \mathrm{q}, 3 \mathrm{p} / \mathrm{q}, 4 \mathrm{p}, 5 \mathrm{q}(39 \%), 9 \mathrm{q}(39 \%), 9 \mathrm{p}, 10 \mathrm{p} / \mathrm{q}, 11 \mathrm{q}(41-45.5 \%), 11 \mathrm{p}, 13 \mathrm{q}$ \\
Syndromes & $(45-53.3 \%), 15 \mathrm{q}, 16 \mathrm{p}(37 \%), 17 \mathrm{q}(36.4 \%), 18 \mathrm{p} / \mathrm{q}, 19 \mathrm{p} / \mathrm{q}, 20 \mathrm{p}$ \\
Gene mutations & Association with Down, Klinefelter syndromes \\
KIT & Gain of function mutations \\
MAPK pathway & KRAS, NRAS, HRAS, RRAS2 \\
\hline
\end{tabular}


Table 3. Cont.

\begin{tabular}{cc}
\hline Genetic Alteration & Genes/Chromosomes; Comments \\
\hline PI3K pathway & AKT, MTOR \\
Overexpressed genes & Expressed at 4q13.3-4q28.3: DDIT4L, BANK1, CXCL9, CXCL11, HERC5, \\
ELOVL6 \\
Genes involving self-renewal mechanisms \\
Other genes & POU5F1 (expressed at chr1q13.13), NANOG, DPP4, KLF4 \\
\hline
\end{tabular}

MiRNA dysregulation

Proposed biomarkers for diagnosis and prognosis

Abbreviations: CNS: central nervous system, KIT: transmembrane protein with tyrosine kinase activity; MAPK: mitogen-activated protein kinase; KRAS: V-Ki-Ras2 Kirsten Rat Sarcoma 2 Viral Oncogene Homolog; NRAS: Neuroblastoma RAS Viral (V-Ras) Oncogene Homolog; HRAS: HRas Proto-Oncogene, GTPase; RRAS2: Ras-related protein R-Ras2; PI3K: phosphoinositide 3-kinase; AKT: v-akt murine thymoma viral oncogene homolog; MTOR: Mammalian Target Of Rapamycin; DDIT4L: DNA Damage Inducible Transcript 4 Like; BANK1: B Cell Scaffold Protein with Ankyrin Repeats 1; CXCL9: C-X-C Motif Chemokine Ligand 9; CXCL11: C-X-C Motif Chemokine Ligand 11; HERC5: HECT and RLD Domain Containing E3 Ubiquitin Protein Ligase 5; ELOVL6: ELOVL Fatty Acid Elongase 6; POU5F1: OCT4, POU Class 5 Homeobox 1; NANOG: Nanog Homeobox; DPP4: Dipeptidyl Peptidase 4; KLF4: Kruppel Like Factor 4; CBL: Casitas B-lineage Lymphoma; NF1: Neurofibromin 1; PTEN: Phosphatase and tensin homolog; BCORL1: BCL6 Corepressor Like 1; NFE2L3: Nuclear factor (erythroid-derived 2)—like 3; HNRNPA2B1: Heterogeneous nuclear ribonucleoprotein A2/B1.

Table 4. Frequency of KIT and RAS mutations in CNS germinoma.

\begin{tabular}{ccc}
\hline Study & KIT Mutation & RAS Mutation \\
\hline Schulte et al. [14] & $17.3 \%$ & $34.6 \%$ \\
Fukushima et al. [86] & $40 \%$ & $20 \%$ \\
Wang et al. [87] & $24 \%$ & $19 \%$ \\
Ichimura et al. [88] & $40 \%$ & $19 \%$ \\
Kamakura et al. [89] & $23 \%$ & Not evaluated \\
Sakuma et al. [90] & $25 \%$ & Not evaluated \\
Gao et al. [91] & $5.9 \%$ & Not evaluated \\
\hline
\end{tabular}

Abbreviations: KIT: transmembrane protein with tyrosine kinase activity; RAS: Rat Sarcoma (oncogene); CNS central nervous system.

Gain of function mutations of KIT proto-oncogene generate a constitutive activation of the KIT protein, which consequently activates signal transduction molecules via MAPK (mitogen-activated protein kinase) or PI3K (phosphoinositide 3-kinase) pathways, resulting in increased cell proliferation, migration, and apoptosis resistance (Figure 5) [86].

However, so far, no correlations have been established between the KIT gene mutation and the expression of the KIT protein or clinical parameters (tumour location, size, and prognosis) [90,91]. The frequency and type of KIT mutation are differently distributed in the population: $5.9 \%$ in the germinomas encountered in the Chinese population (missense mutation in exon 11), whereas $23-25 \%$ in the Japanese patients (75\% affecting the exon 17 and $25 \%$ the exon 11 , others involving exons 2,13 ) [89-91]. Another study mentions exon 10 variant (c.1621A $>C$ ) as the most common encountered in germinomas, other KIT exonic variants including exon 2 (c.251C > T), exon 11 (c.1658A $>$ G), exon 13 (c.1965T>A), exon 17 (c.2447A>T) [92]. Nevertheless, 27.4\% of CNS GCT have no detectable KIT mutations, even though KIT expression by IHC is high, suggesting implication of other mechanisms [88]. For example, $C B L$ is a tumour suppressor gene involved in the process of down-regulation of the KIT receptor, and its mutation causes sustained KIT activation. Somatic mutations in the CBL gene are frequently encountered in ICGCT and represent another cause of KIT overexpression in germinomas $[87,88]$.

The PISK/AKT and MAPK pathways seem to be widely implicated in the pathogenesis of germinoma, being present simultaneously in $83 \%$ of tumour cells [14]. MAPK pathway alterations are more frequent in germinomas than NGGCT and have a tendency to correlate with a better prognosis, in comparison with PI3K pathway mutations. Upregulation of $M A P K$ pathway by somatic point mutations represents the dominant genetic alteration in germinomas (64.3\% of cases) [88]. These cases are more frequent in male patients and seem to be associated with an elevated serum HCG [7]. A case of 16p11.2 microdeletion was associated with the presence of bifocal germinoma, presumably due to deletion of 
MAPK3 gene [93]. Amplification of 12p involves the KRAS gene (a component of MAPK pathway) and seems to be playing an important role in germinomas, similar to testicular germ cell tumours [14]. Furthermore, NF-1, a negative regulator of MAPK pathway, can present mutations in both germinomas and NGGCT [88].

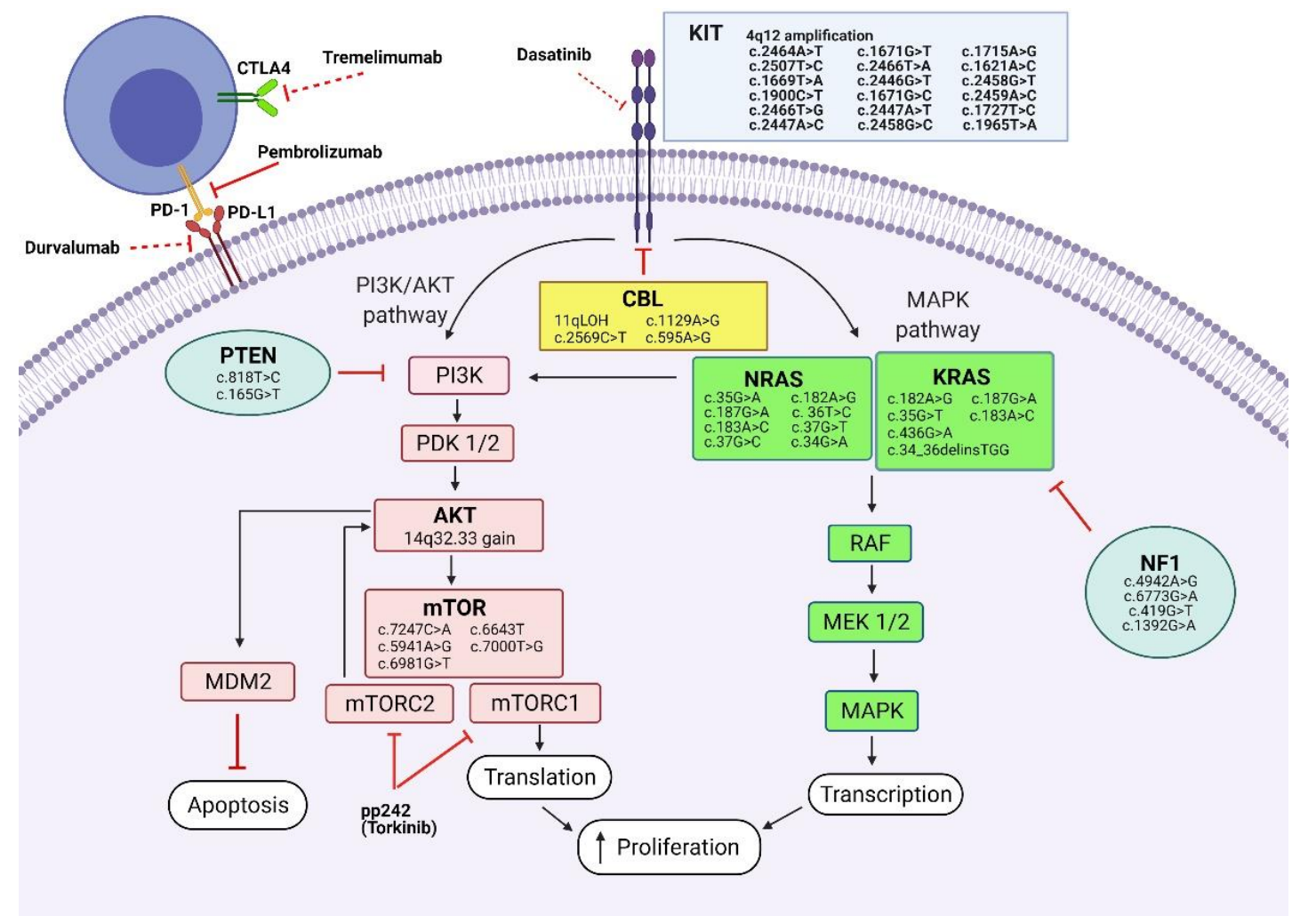

Figure 5. (Created with BioRender.com) Signalling pathways, genetic mutations and potential targeted treatment involved in CNS germinoma development. Tumourigenesis in germinoma is stimulated through various mechanisms. Activating KIT mutations promote cell proliferation via PI3K/AKT and MAPK pathways. Molecular aberrations involving the PISK/AKT pathway result in increased proliferation via mTORC1 and cell survival by apoptosis inhibition via mTORC2. MAPK pathway mutations promote cell proliferation. Potential targeted treatment (KIT inhibitors, immune checkpoint inhibitors, mTOR inhibitors) are presented. Gene mutations identified in CNS germinomas are depicted alongside each gene. Abbreviations: KIT: tyrosine kinase receptor; CBL: casitas B-lineage lymphoma; KRAS: Kirsten rat sarcoma viral oncogene homologue; NRAS: neuroblastoma RAS viral oncogene homolog; RAF: rapidly accelerated fibrosarcoma kinase; MEK: mitogen-activated protein/extracellular signal-regulated kinase kinase; MAPK: mitogen-activated protein kinase; PI3K: phosphatidylinositol-3-kinase; PDK: pyruvate dehydrogenase kinase; AKT: v-akt murine thymoma viral oncogene homolog; mTOR: the mechanistic target of rapamycin; mTORC—-mTOR complex; PD-1: programmed cell death protein 1; PD-L1: programmed death-ligand 1; CTLA4: cytotoxic T-lymphocyte-associated protein 4.

Upregulation of PI3K pathway is the second genetic event involved in germinoma pathogenesis, MTOR gene being frequently mutated [88]. MTOR mutation promotes cell proliferation via $m T O R C 1$ and cell survival via $m T O R C 2$ and $A K T$. These effects were downregulated by pp242, an MTOR inhibitor, underlining the therapeutic prospects in germinoma [88]. Basal ganglia germinomas appear to frequently present $P I 3 K / m T O R$ pathway mutations and chromosomal losses $(1 \mathrm{p}, 3 \mathrm{p} / \mathrm{q}, 4 \mathrm{p}, 9 \mathrm{p} / \mathrm{q}, 10 \mathrm{p} / \mathrm{q}, 11 \mathrm{p}, 13 \mathrm{q}, 18 \mathrm{p} / \mathrm{q}$, $19 \mathrm{p} / \mathrm{q}$, and 20p) [7]. Therefore, blockade therapy targeting these pathways may represent an alternative for germinomas that fail to respond to the standard regimens.

Compared to NGGCT, germinomas present with overexpression of genes within 4q13.3-4q28.3 and genes involved in self-renewal mechanisms (see Table 3) that have the capacity to induce dedifferentiation of matured somatic cells to pluripotent embryonic stem cells [94]. Takayasu et al. suggest that gene mutation analysis using CSF circulating 
tumour DNA is also a feasible study method in germinomas [95]. Genes reported in at least two distinct studies, and their genetic alterations are presented in Table 5.

Table 5. Genes with possible pathogenic role in germinomas, reported in at least two distinct studies.

\begin{tabular}{|c|c|c|c|c|}
\hline Study & Chr. & Gene & AA Mutation & CDS Mutation \\
\hline $\begin{array}{c}\text { Ichimura et al. [88] } \\
\text { Schulte et al. [14] } \\
\text { Fukushima et al. [86] } \\
\text { Wang et al. [87] } \\
\text { Sakuma et al. [90] } \\
\text { Takayasu et al. [95] } \\
\text { Low et al. [92] }\end{array}$ & $4 q 12$ & KIT & $\begin{array}{c}\text { p.Asn822Tyr } \\
\text { p.Met836Thr } \\
\text { p.557W>R } \\
\text { p.Arg634Trp } \\
\text { p.Asn822Lys } \\
\text { p.Asp816Ala } \\
\text { p.Asn655Lys } \\
\text { p.820D>Y } \\
\text { p.Asp572Gly } \\
\text { p.Trp557Cys } \\
\text { p.Asn822Lys } \\
\text { p.Asp816Tyr } \\
\text { p.Trp557Cys } \\
\text { p.Asp816Val } \\
\text { p.Asp820His } \\
\text { p.Leu576Pro } \\
\text { p.D820A } \\
\text { p.M541L }\end{array}$ & $\begin{array}{l}c .2464 A>T \\
c .2507 T>C \\
c .1669 T>A \\
c .1900 C>T \\
c .2466 T>G \\
c .2447 A>C \\
c .1965 T>A \\
c .2458 G>T \\
c .1715 A>G \\
c .1671 G>T \\
c .2466 T>A \\
c .2446 G>T \\
c .1671 G>C \\
c .2447 A>T \\
c .2458 G>C \\
c .1727 T>C \\
c .2459 A>C \\
c .1621 A>C\end{array}$ \\
\hline & & & \multicolumn{2}{|c|}{$+4 q 12$ amplification } \\
\hline \multirow[t]{2}{*}{$\begin{array}{l}\text { Ichimura et al. [88] } \\
\text { Schulte et al. [14] } \\
\text { Fukusima et al. [86] } \\
\text { Wang et al. [87] }\end{array}$} & $12 \mathrm{p} 12.1$ & KRAS & $\begin{array}{c}\text { p.63E }>K \\
\text { p.Gln61Arg } \\
\text { p.Gly12 Val } \\
\text { p.Gln61His } \\
\text { p.146A }>\mathrm{T} \\
\text { p.G12W }\end{array}$ & $\begin{array}{c}c .182 A>G \\
c .187 G>A \\
c .35 G>T \\
\text { c. } 183 \mathrm{~A}>\mathrm{C} \\
\text { c. } 436 \mathrm{G}>\mathrm{A} \\
\text { c.34_36delinsTGG }\end{array}$ \\
\hline & & & \multicolumn{2}{|c|}{+12 p12 amplification } \\
\hline $\begin{array}{l}\text { Ichimura et al. [88] } \\
\text { Schulte et al. [14] } \\
\text { Fukushima et al. [86] } \\
\text { Wang et al. [87] } \\
\text { Takayasu et al. [95] }\end{array}$ & 1p13.2 & NRAS & $\begin{array}{c}\text { p.12G>D } \\
\text { p.Glu63Lys } \\
\text { p.Gln61His } \\
\text { p.Gly13Arg } \\
\text { p.Q61R } \\
\text { p.G12B } \\
\text { p.G13C } \\
\text { p.G12S }\end{array}$ & $\begin{array}{c}c .35 \mathrm{G}>A \\
\text { c. } 187 \mathrm{G}>\mathrm{A} \\
\text { c. } 183 \mathrm{~A}>\mathrm{C} \\
\mathrm{c} .37 \mathrm{G}>\mathrm{C} \\
\mathrm{c} 182 \mathrm{~A}>\mathrm{G} \\
\mathrm{c.} 36 \mathrm{~T}>\mathrm{C} \\
\text { c. } 37 \mathrm{G}>\mathrm{T} \\
\text { c. } 34 \mathrm{G}>\mathrm{A}\end{array}$ \\
\hline $\begin{array}{c}\text { Ichimura et al. [88] } \\
\text { Fukushima et al. [86] }\end{array}$ & $11 \mathrm{p} 15.5$ & $H R A S$ & p.61Q>R & c. $182 A>G$ \\
\hline \multirow[t]{2}{*}{$\begin{array}{l}\text { Ichimura et al. [88] } \\
\text { Schulte et al. [14] }\end{array}$} & $11 \mathrm{p} 15.2$ & RRAS2 & $\begin{array}{l}\text { p.Gly23Cys } \\
\text { p.G23A } \\
\text { p.G23S } \\
\text { p.G24C } \\
\text { G24D }\end{array}$ & $\begin{array}{c}\mathrm{c.67G}>\mathrm{T} \\
\mathrm{GGC} \rightarrow \mathrm{GCC} \\
\mathrm{GGC} \rightarrow \mathrm{AGC} \\
\mathrm{GGC} \rightarrow \mathrm{TGC} \\
\mathrm{GGC} \rightarrow \mathrm{GAC}\end{array}$ \\
\hline & & & \multicolumn{2}{|c|}{ +11p15.2 amplification } \\
\hline $\begin{array}{l}\text { Ichimura et al. [88] } \\
\text { Wang et al. [87] }\end{array}$ & $1 \mathrm{p} 36.22$ & MTOR & $\begin{array}{c}\text { p.Ala2416Asp } \\
\text { p.Lys1981Glu } \\
\text { p.2327M }>\mathrm{I} \\
\text { p.2334L }>\text { V } \\
\text { p.Ser2215Pro }\end{array}$ & $\begin{array}{l}\text { c. } 7247 \mathrm{C}>\mathrm{A} \\
\text { c. } 5941 \mathrm{~A}>\mathrm{G} \\
\text { c. } 6981 \mathrm{G}>\mathrm{T} \\
\text { c. } 7000 \mathrm{~T}>\mathrm{G} \\
\text { c. } 6643 \mathrm{~T}>\mathrm{C}\end{array}$ \\
\hline
\end{tabular}


Table 5. Cont.

\begin{tabular}{|c|c|c|c|c|}
\hline Study & Chr. & Gene & AA Mutation & CDS Mutation \\
\hline $\begin{array}{l}\text { Ichimura et al. [88] } \\
\text { Wang et al. [87] }\end{array}$ & $11 \mathrm{q} 23.3$ & $C B L$ & $\begin{array}{l}\text { p.Leu857Phe } \\
\text { p.Thr377Ala } \\
\text { p.Ile199Val }\end{array}$ & $\begin{array}{l}\text { c. } 2569 \mathrm{C}>\mathrm{T} \\
\text { c. } 1129 \mathrm{~A}>\mathrm{G} \\
\text { c. } 595 \mathrm{~A}>\mathrm{G}\end{array}$ \\
\hline & & & \multicolumn{2}{|c|}{$+11 q L O H$} \\
\hline $\begin{array}{l}\text { Ichimura et al. [88] } \\
\text { Schulte et al. [14] }\end{array}$ & $17 q 11$ & NF1 & $\begin{array}{l}\text { p.Thr1648Ala } \\
\text { p.Arg2258Gln } \\
\text { p.Gly140Val }\end{array}$ & $\begin{array}{c}\text { c. } 4942 \mathrm{~A}>\mathrm{G} \\
\text { c. } 6773 \mathrm{G}>\mathrm{A} \\
\text { c. } 419 \mathrm{G}>\mathrm{T} \\
\text { c.1392G }>\mathrm{A} \\
\text { (possible splice } \\
\text { site disruption) }\end{array}$ \\
\hline $\begin{array}{c}\text { Ichimura et al. [88] } \\
\text { Takami et al. [7] }\end{array}$ & $10 q 23.31$ & PTEN & $\begin{array}{l}\text { p.Phe273Ser } \\
\text { p.Arg55Ser }\end{array}$ & $\begin{array}{l}\text { c. } 818 \mathrm{~T}>\mathrm{C} \\
\text { c. } 165 \mathrm{G}>\mathrm{T}\end{array}$ \\
\hline $\begin{array}{l}\text { Ichimura et al. [88] } \\
\text { Wang et al. [87] }\end{array}$ & Xq26.1 & BCORL1 & p.Thr853Asn & $\begin{array}{c}\text { c. } 2558 \mathrm{C}>\mathrm{A} \\
\text { c. } 1924 \mathrm{Cdel} \\
\text { c. } 4700 \mathrm{AAdel}\end{array}$ \\
\hline $\begin{array}{l}\text { Schulte et al. [14] } \\
\text { Wang et al. [94] }\end{array}$ & 7p15.2-p14 & NFE2L3 & \multicolumn{2}{|c|}{ Chromosome number gains } \\
\hline $\begin{array}{l}\text { Ichimura et al. [88] } \\
\text { Schulte et al. [14] }\end{array}$ & $7 \mathrm{p} 15.2$ & HNRNPA2B1 & $\begin{array}{c}\text { r.spl10 } \\
\text { p.Ser212 * } \\
\text { p. } 69 \mathrm{~F}>\mathrm{S}\end{array}$ & $\begin{array}{c}\text { INV10+1G }>\mathrm{T} \\
\text { c. } 635 \mathrm{C}>\mathrm{A} \\
\text { c. } 206 \mathrm{~T}>\mathrm{C} \\
\text { c. } 878-1 \mathrm{G}>\mathrm{C} \\
\text { (possible splice } \\
\text { site disruption) }\end{array}$ \\
\hline
\end{tabular}

The genes showed in the table have been reported as mutated in CNS germinomas in at least two distinct studies. Only KIT mutations reported in at least two studies are presented. Other gene's mutations validated in more than one study are written in italics. Mutations reported only once are written normally. Abbreviations: chr: chromosome; AA mutation: amino acid mutation (the change in the amino acid sequence caused by the mutation); CDS mutation: coding DNA sequence mutation (the change in the nucleotide sequence caused by the mutation); KIT: Receptor Tyrosine Kinase; KRAS: V-Ki-Ras2 Kirsten Rat Sarcoma 2 Viral Oncogene Homolog NRAS: Neuroblastoma RAS Viral (V-Ras) Oncogene Homolog; HRAS: HRas Proto-Oncogene, GTPase; RRAS2: Ras-related protein R-Ras2; MTOR: Mammalian Target Of Rapamycin; CBL: Casitas B-lineage Lymphoma; NF1: Neurofibromin 1; PTEN: Phosphatase and tensin homolog; BCORL1: BCL6 Corepressor Like 1; NFE2L3: Nuclear factor (erythroid-derived 2)-like 3; HNRNPA2B1: Heterogeneous nuclear ribonucleoprotein A2/B1; the symbol "*”" marks the stop codon.

Recently, microRNAs (miRNAs) have been evaluated as possible biomarkers for various pathologies. MiRNAs are small, noncoding RNA molecules, involved in posttranscriptional gene regulation. GCT are associated with up-regulation of the miR-371 373 and miR-302 clusters, disregarding tumour site, age, or histopathologic type [96]. MiR-371a$3 p$ was identified as a reliable marker in the differential diagnosis between germinoma and Langerhans cell histiocytosis, granting an early detection in cases where imaging studies and serum/CSF work-up are inconclusive [97]. A prospective observational cohort study is currently recruiting patients to evaluate whether miRNA 371 can be used as a prognostic marker for the risk of GCT recurrence [98]. MiR-142-5p and miR-146a are upregulated in the paediatric CNS germinoma, the former inversely correlating with NRP1 (Neuropilin 1), SVIL (Supervillin), and PDGFRA (Platelet Derived Growth Factor Receptor Alpha) and the latter with RUNX1T1 (RUNX1 Partner Transcriptional Co-Repressor 1) and THRB (Thyroid Hormone Receptor Beta) [94]. Low et al. observed a persistent correlation between KIT and downregulation of MiR-221-3p, although further studies are needed to validate this association and evaluate its clinical implications. Downregulation of miR-503 is also encountered in germinomas (Table 6) [92]. 
Table 6. Up and downregulation of miRNAs in GCT.

\begin{tabular}{ccc}
\hline Study & Upregulated & Downregulated \\
\hline Murray et al. 2020 [97] & miR-371a-3p & \\
Low et al. 2020 [92] & miR-373-3p & miR-571 \\
& miR-373-5p & miR-503-5p \\
& miR-455-5p & miR-324-5p \\
& miR-650 & miR-221-3p \\
MiR-183-5p & miR-132-3p \\
miR-373-3p & \\
Wurray et al. 2016 [99] & miR-367-3p & \\
& miR-302a-3p & \\
\hline Abbreviations: miRNA: microRNA. GCT: germ cell tumours. & \\
\hline
\end{tabular}

Abbreviations: miRNA: microRNA; GCT: germ cell tumours.

\section{Immunological Approach}

Other factors seem to be involved in the pathophysiology of germinomas, tumour immune microenvironment being one of them [73]. Paradoxically, the large immune infiltrate encountered in germinomas seems to have no antitumour effect, and several studies aimed to evaluate the role of the programmed death receptor 1 (PD-1)/programmed death receptor 1 ligand (PD-L1) pathway, after it has been reported that PD-L1 is expressed by testicular seminomas, the gonadal counterpart to CNS germinomas [100]. The interaction between the ligand PD-L1, expressed by tumour cells, and PD-1 localised on activated lymphocytes induces T-cell anergy and downregulates the immune response. A small study of 8 patients with intracranial germinoma showed in all patients PD-L1 staining of the tumour cells and PD-1 expression of the tumour-infiltrating lymphocytes (TILs) and found a correlation between the immunosuppressive microenvironment and the growth of the tumours [101]. Takami et al. evaluated the tumour immune microenvironment in 32 germinoma cases, concluding that tumour cells have a $73.5 \%$ positivity for PD-L1, while the majority of infiltrating, stained immune cells are PD-1 positive $(93.8 \%)$, making germinomas a proper candidate for immunotherapy [102]. The high expression of CD4 T helper lymphocytes correlates with a good prognosis, while great levels of nitric oxide synthase 2 produced by myeloid-derived suppressor cells and macrophages associates with a shorter progression free survival (PFS), possibly by generating immune tolerance [102]. Although there are some discrepancies between studies (Table 7), the role of PD-1/PDL1 pathway in germinomas warrants further investigation and may offer new potential therapeutic perspectives.

Table 7. Germinoma immune microenvironment.

\begin{tabular}{cccc}
\hline Study & $\begin{array}{c}\text { No. } \\
\text { Cases }\end{array}$ & $\begin{array}{c}\text { PD-L1 Expression } \\
\text { (Tumour Cells) }\end{array}$ & $\begin{array}{c}\text { PD-1 Expression } \\
\text { (Immune Cells) }\end{array}$ \\
\hline Nishimoto et al. 2020 [101] & 8 & $100 \%$ & $100 \%$ TILs \\
Takami et al. 2019 [102] & 32 & $73.5 \%$ & $93.8 \%$ immune cells \\
Liu et al. 2018 [103] & 25 & $92 \%$ & $96 \%$ TILs \\
Wildeman et al. 2018 [104] & 21 & $90 \%$ & $48 \%$ lymphocytes, stromal cells \\
Zapka et al. 2017 [73] & 28 & $0 \%$ & $11.9 \%$ TILs \\
\hline
\end{tabular}

Abbreviations: no: number; PD-L1: programmed death receptor 1 ligand; PD-1: programmed death receptor 1; TILs: tumour-infiltrating lymphocytes. 


\section{Current Management}

The treatment of intracranial germinomas is multidisciplinary, including surgery, chemotherapy, radiotherapy (RT), and endocrine therapy. Germinomas are distinctively radiosensitive, with overall survival rates of over $90 \%$, with radiation therapy alone $[6,22,105,106]$. Chemotherapy alone can induce complete remissions in $84 \%$ of the cases, but the long-term efficacy has been proven to be unsatisfactory, with high rates of morbidity and mortality, only $50 \%$ of the patients being treated successfully by this method [107-109]. Therefore, the standard treatment is represented by a combination of chemotherapy (Carboplatin/Cisplatin and Etoposide \pm Ifosfamide) and radiotherapy $[110,111]$. Nevertheless, surgical resection is commonly performed as the first therapeutic option. The largest multicentre analysis of pituitary germinomas (SEER-Surveillance, Epidemiology, and End Result program) showed that chemotherapy was used more frequently in paediatrics, whereas surgery being applied in the adult population [112].

However, given the high radiosensitivity of germinomas, the extensive tumour resection is not necessary for a complete response, the surgery approach being currently limited to the treatment of hydrocephalus and a tumour biopsy in order to obtain a histological diagnosis. Obstructive hydrocephalus represents a severe complication and requires appropriate management. Until recently, increased intracranial pressure was relieved by ventriculoperitoneal shunts. However, it was discovered that this technique involves a high risk of peritoneal metastasis of the primary GCT and that patients require a thorough follow-up with CT scans of the abdomen to detect metastatic disease [113]. Nowadays, hydrocephalus can be treated by performing endoscopic ventriculostomy, without the risk of peritoneal metastasis [37]. Different techniques have been proposed for the approach, combining third ventriculostomy (ETV) with endoscopic biopsy. Usually, posterior third ventricle tumours are approachable through two trajectories, necessitating two burr holes or one "compromised" burr hole. Roth et al. performed this combined technique through a single burr hole, using a rigid endoscope to perform the ETV, followed by a flexible one to retrieve the biopsy sample, with favourable results. The benefits of this technique are represented by the necessity of a single burr hole, a better visualization of the tumour offered by the rigid endoscope, and a better access offered by the flexible one [114]. Moreover, a combined intervention for pineal tumours, using a single burr hole and a rigid endoscope for both ETV and biopsy, was successfully performed. The larger forceps of the rigid endoscope have the advantage of obtaining larger samples in comparison with flexible endoscopes [71,115]. Supracerebellar infratentorial approach, performed by microsurgery or endoscopic techniques, is a feasible alternative in cases of pineal tumours. The endoscopic approach offers a better visualization of the tumour, a wider range of motion of surgical instruments, a shorter duration of the procedure, a quick recovery, and fewer complications [116,117]. Second-look surgery should be considered in patients with residual tumour or high serum/CSF markers after an appropriate treatment protocol. In these instances, it is possible that the tissue sample was insufficient, containing only the germinomatous component of a tumour with a mixed histology [118,119].

The treatment for localized disease may consist of either craniospinal irradiation (CSI) alone, or chemotherapy and reduced-field radiotherapy. Whole ventricular irradiation (WVI) is recommended, as the ventricles and periventricular areas represent a frequent site of relapse $[76,120]$. Most studies recommend chemoradiotherapy (CRT), to avoid whole brain irradiation (WBI) and CSI and the adverse effects of radiotherapy. In addition, Zhang et al. suggest that limited radiotherapy represents a feasible treatment strategy for bifocal germinomas, without metastasis, as well [121]. This method of treatment ensured the achievement of long-term survival rates as high as 95-97\% [122,123]. In addition, a prospective multicentre cohort study revealed that relapse rates could be reduced by adapting the RT volume as follows: whole ventricle radiotherapy (WVRT) for localized pineal/suprasellar lesions, whole-brain radiotherapy (WBRT) for localized basal ganglia/thalamus, and CSI for disseminated disease [124]. Moreover, in an analysis of 253 cases of CNS germinomas, Jennings et al. reported that signs and symptoms 
suggestive of hypothalamic-pituitary axis dysfunction should steer the treatment towards CSI and systemic chemotherapy [125]. Optimal RT dosage and field inclusion are still under debate. Selected prospective studies evaluating different treatment regimens (doses of chemotherapy and radiotherapy), and their conclusions are summarized in Table 8, and retrospective studies are resumed in Appendix A Table A1. We conducted a PubMed search for English written articles regarding intracranial germinomas, published between 1996-2021. The articles were selected based on a combination of search terms (germinoma, intracranial, CNS, germ cell tumour, pineal, suprasellar, bifocal, paediatric, treatment, radiotherapy, chemotherapy). We analysed studies evaluating solely germinomas, as well as studies evaluating a wider range of germ cell tumours, provided germinomas were included.

As far as the radiotherapy techniques are concerned, proton beam therapy (passively scattered proton therapy and spot scanning proton therapy) delivers lower doses of radiation to the healthy tissue surrounding the tumour, sparing greater volumes of the temporal lobes and hippocampus than intensity-modulated radiotherapy (IMRT) [126]. 
Table 8. Prospective studies regarding treatment regimes in CNS germinomas.

\begin{tabular}{|c|c|c|c|c|}
\hline Study & Chemotherapy Regimen \pm Surgery & Radiotherapy & Results & Conclusion \\
\hline $\begin{array}{c}\text { Lee et al. } 2019 \text { [124] } \\
\text { Prospective, multicentre, cohort study } \\
\text { Bifocal germinomas treated as } \\
\text { disseminated disease } \\
91 \text { germinoma patients: } \\
65 \text { localized diseases } \\
9 \text { bifocal diseases } \\
17 \text { multiple/disseminated cases } \\
\text { Median age }=14 \text { years } \\
74.7 \% \text { male patients }\end{array}$ & $\begin{array}{l} \pm \text { Surgery: total/partial resection } \\
\text { (11\%)/biopsy }(89 \%) \\
2 \text { courses of: } \\
\text { Etoposide } 150 \mathrm{mg} / \mathrm{m}^{2} \\
\text { Carboplatin } 450 \mathrm{mg} / \mathrm{m}^{2} \\
\text { alternating with } \\
2 \text { courses of: } \\
\text { Etoposide } 150 \mathrm{mg} / \mathrm{m}^{2} \\
\text { Cyclophosphamide } 1000 \mathrm{mg} / \mathrm{m}^{2}\end{array}$ & $\begin{array}{c}\text { Localized disease: } \\
\text { CR: focal RT (30.6 Gy) } \\
\text { PR: CSI (19.5 Gy) + focal RT (19.8 } \\
\text { Gy) } \\
\text { Bifocal/multiple/disseminated } \\
\text { disease: } \\
\text { CR: CSI (19.5 Gy) + focal } \\
\text { RT (10.8 Gy) } \\
\text { PR: CSI (24 Gy) + focal RT (16.2 Gy) }\end{array}$ & $\begin{array}{c}\text { Median FU }=5.6 \text { years } \\
4 \text { patients with } \\
\text { progression } / \text { recurrence } \\
(4.4 \%) \\
\text { 5-year OS }=98.8 \% \\
\text { 5-year PFS }=96.6 \%\end{array}$ & $\begin{array}{l}\text { RT for localized } \\
\text { pineal/suprasellar germinomas } \\
\text { should include the whole } \\
\text { ventricle area, whereas basal } \\
\text { ganglia/thalamus germinomas } \\
\text { should be treated with WBRT. }\end{array}$ \\
\hline \multirow{3}{*}{$\begin{array}{c}\text { Calaminus et al. SIOP 96, } 2013 \text { [76] } \\
\text { Prospective, multinational, } \\
\text { nonrandomized study } \\
235 \text { germinoma patients: } \\
190 \text { localized diseases: } 93 \text { pineal; } 53 \\
\text { supra-/intrasellar; } 32 \text { bifocal; } 11 \text { other } \\
45 \text { disseminated cases: } 17 \text { pineal, } 13 \\
\text { supra-/intrasellar, } 15 \text { bifocal } \\
\text { Median age }=13 \text { years } \\
176 \text { males } \\
59 \text { females }\end{array}$} & $\begin{array}{c} \pm \text { Surgery: } 22 \text { complete resections, } 107 \text { subtotal } \\
\text { resections /open biopsies, } 103 \text { stereotactic } \\
\text { biopsies } \\
\text { Local } / \text { bifocal disease } \\
\text { Carboplatin } 600 \mathrm{mg} / \mathrm{m}^{2} / \text { day+ } \\
\text { Etoposide } 100 \mathrm{mg} / \mathrm{m}^{2} / \text { day } \\
\text { alternating with } \\
\text { Etoposide } 100 \mathrm{mg} / \mathrm{m}^{2} / \text { day+ } \\
\text { Ifosfamide } 1800 \mathrm{mg} / \mathrm{m}^{2} / \text { day }\end{array}$ & $\begin{array}{l}\text { Local/bifocal disease: } \\
\text { Focal RT ( } 40 \text { Gy) }\end{array}$ & $\begin{array}{l}\text { Median FU }=6 \text { years } \\
5 \text {-year PFS }=88 \% \\
\text { OS }=96 \% \\
7 \text { recurrences (6 with } \\
\text { ventricular relapse) }\end{array}$ & \multirow{3}{*}{$\begin{array}{l}\text { Ventricular relapses suggest the } \\
\text { importance of WVRT } \\
\text { Local/bifocal germinomas are } \\
\text { successfully treated with } \\
\text { reduced dose CSI or with } \\
\text { chemotherapy and reduced field } \\
\text { RT }\end{array}$} \\
\hline & No chemotherapy & $\begin{array}{c}\text { CSI } 24 \mathrm{~Gy}+\text { primary tumour site } \\
\text { boost } 16 \mathrm{~Gy}\end{array}$ & $\begin{array}{c}\text { 5-year PFS }=97 \% \\
\text { OS }=95 \% \\
4 \text { recurrences at original } \\
\text { site }\end{array}$ & \\
\hline & $\begin{array}{c}\text { Disseminated disease } \\
\pm \text { Chemotherapy (same regimen) }\end{array}$ & $\begin{array}{c}\text { Disseminated disease } \\
24 \text { Gy CSI }+16 \text { Gy boost at primary } \\
\text { tumour site and metastases }\end{array}$ & $\begin{array}{l}5 \text {-year PFS }=100 \% \\
\text { OS }=98 \%\end{array}$ & \\
\hline $\begin{array}{c}\text { Kretschmar et al. POG } 2007 \text { [127] } \\
\text { Prospective, phase II study } \\
12 \text { germinomas: } \\
8 \text { localized diseases: } 2 \text { pineal, } 2 \text { basal } \\
\text { ganglia, } 1 \text { suprasellar, } 3 \text { other } \\
4 \text { disseminated cases } \\
\text { Median age }=15.1 \text { years } \\
10 \text { male patients, } 2 \text { female patients }\end{array}$ & $\begin{array}{c} \pm \text { Surgery: } 5 / 12 \text { patients: partial/total resection } \\
4 \text { courses } \\
\text { Cisplatin } 20 \mathrm{mg} / \mathrm{m}^{2} / \text { day+ } \\
\text { Etoposide } 100 \mathrm{mg} / \mathrm{m}^{2} / \text { day } \\
\text { alternating with } \\
\text { Vincristine } 1.5 \mathrm{mg} / \mathrm{m}^{2}+\text { Cyclophosphamide } \\
(\mathrm{CPM}) 1 \mathrm{~g} / \mathrm{m}^{2} / \text { day }\end{array}$ & $\begin{array}{c}\text { CR: primary site RT } 30.6 \mathrm{~Gy} ; \\
\text { PR: primary site RT } 50.4 \mathrm{~Gy} \text { with } 2 \\
\text { cm margin (3D-CRT) or } 0.5 \mathrm{~cm} \\
\text { margin (SRT) } \\
\text { Disseminated disease: } \\
\text { CR: CSI } 30.6 \mathrm{~Gy}+\text { local boost } 50.4 \\
\text { Gy } \\
\text { PR: CSI } 36 \mathrm{~Gy}+\text { local boost } 54 \mathrm{~Gy}\end{array}$ & $\begin{array}{c}\text { Median FU: } 5.5 \text { years } \\
11 / 12 \text { progression-free at } \\
\text { median } 5.5 \text { years } \\
1 / 12 \text { refused } R T \text {, recurred } \\
\text { at } 10 \text { months, salvage } \\
\text { CSI, progression-free at } \\
4.8 \text { years }\end{array}$ & $\begin{array}{c}\text { Favourable response }(91 \%) \text { and } \\
\text { survival in the setting of } \\
\text { chemotherapy followed by } \\
\text { response-based RT }\end{array}$ \\
\hline
\end{tabular}


Table 8. Cont.

\begin{tabular}{|c|c|c|c|c|}
\hline Study & Chemotherapy Regimen \pm Surgery & Radiotherapy & Results & Conclusion \\
\hline $\begin{array}{c}\text { Aoyama et al. } 2002 \text { [118] } \\
\text { Prospective study, phase II } \\
27 \text { germinomas out of } 33 \text { ICGCT: } \\
\text { 16 pure germinomas } \\
8 \text { localized diseases: } 1 \text { neurohypophysis, } \\
7 \text { pineal } \\
6 \text { multifocal diseases: } 4 \\
\text { neurohypophysis + pineal } \pm \text { ventricle, } 1 \\
\text { neurohypophysis + ventricle, } 1 \text { bilateral } \\
\text { basal ganglia } \\
2 \text { disseminated cases } \\
\text { 11 } \beta \text {-HCG secreting germinoma } \\
8 \text { localized diseases: } 6 \text { neurohypophysis, } \\
2 \text { pineal } \\
2 \text { multifocal diseases: neurohypophysis } \\
+ \text { pineal } \\
1 \text { disseminated case } \\
\text { Mean age = } 15.9 \text { years (including } \\
\text { patients with NGGCT) } \\
32 \text { males, } 1 \text { female (including patients } \\
\text { with NGGCT) }\end{array}$ & $\begin{array}{c} \pm \text { Surgery }-3 \text { gross total/3 partial resections, } \\
10 \text { biopsies for pure germinomas; } \\
1 \text { gross total/3 partial resections, } 7 \text { biopsies for } \\
11 \beta \text {-HCG secreting germinoma } \\
\text { Localised disease: } \\
\text { Etoposide }\left(100 \mathrm{mg} / \mathrm{m}^{2}\right)+\text { Cisplatin }\left(20 \mathrm{mg} / \mathrm{m}^{2}\right) \\
5 \text { consecutive days every } 4 \text { weeks } \\
-4 \text { cycles after partial resection } / \text { biopsy } \\
-3 \text { cycles after total/subtotal resection } \\
\text { Multifocal/disseminated disease }+ \\
\beta \text {-HCG-secreting germinomas: } \\
3-6 \text { cycles of ICE: } \\
\text { Ifosfamide }\left(900 \mathrm{mg} / \mathrm{m}^{2}\right)+\text { Cisplatin }(20 \\
\left.\mathrm{mg} / \mathrm{m}^{2}\right)+ \text { Etoposide }\left(60 \mathrm{mg} / \mathrm{m}^{2}\right) \\
5 \text { consecutive days every } 4 \text { weeks. } \\
\text { Recurrence: chemotherapy } \\
\text { and reirradiation }\end{array}$ & $\begin{array}{c}\beta \text {-HCG secreting germinomas: } \\
\text { Local irradiation/ } \\
\text { 24-Gy WVRT+ } \\
6 \text { Gy neurohypophysis + } 10 \text { Gy } \\
\text { pineal region } \\
\text { Multifocal: } 24 \text { Gy WVRT } \\
\text { Disseminated: } 24 \text { Gy CSI }\end{array}$ & $\begin{array}{c}\beta \text {-HCG-secreting } \\
\text { germinomas: } \\
\text { CR }=100 \% \\
\text { 5-year free survival rate } \\
=44 \% \\
5 \text { recurrences } \\
\text { No death due to } \\
\text { recurrence }\end{array}$ & $\begin{array}{l}\text { WV or larger field irradiation } \\
\text { (probably } 30-40 \text { Gy) is necessary } \\
\text { for } \beta \text {-HCG secreting } \\
\text { germinomas } \\
\text { 24-Gy irradiation to the primary } \\
\text { site in combination with EP } \\
\text { chemotherapy yielded excellent } \\
\text { results in solitary pure } \\
\text { germinomas }\end{array}$ \\
\hline
\end{tabular}


Table 8. Cont.

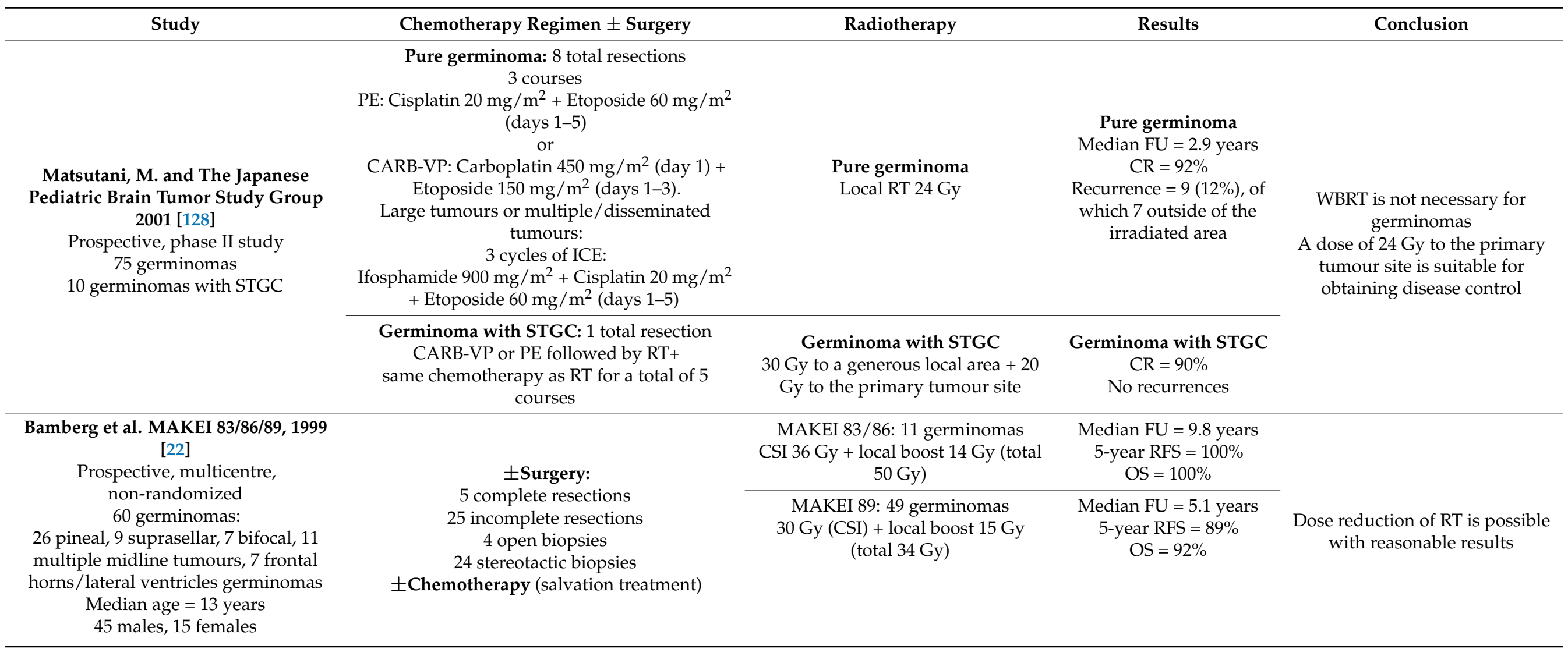


Table 8. Cont.

\begin{tabular}{|c|c|c|c|c|}
\hline Study & Chemotherapy Regimen \pm Surgery & Radiotherapy & Results & Conclusion \\
\hline $\begin{array}{l}\text { Bouffet et al. SFOP- } 1999 \text { [129] } \\
\text { Prospective, multicentre study } \\
57 \text { germinomas: } \\
20 \text { pineal, } 28 \text { suprasellar, } 2 \text { thalamic, } 7 \\
\text { bifocal, } 6 \text { disseminated cases } \\
\text { Median age }=13.5 \text { years } \\
43 \text { males, } 14 \text { females }\end{array}$ & $\begin{array}{c} \pm \text { Surgery: } 6 \text { total resections, } 12 \text { partial } \\
\text { resections, } 7 \text { open biopsies, } 22 \text { stereotactic } \\
\text { biopsies } \\
4 \text { courses: } \\
\left.\text { Carboplatin } 600 \mathrm{mg} / \mathrm{m}^{2} \text { (day } 1\right)+ \\
\text { Etoposide } 150 \mathrm{mg} / \mathrm{m}^{2} / \text { day (days } 1 \text { to } 3 \text { ) } \\
\text { alternating with } \\
\left.\text { Ifosfamide } 1.8 \mathrm{~g} / \mathrm{m}^{2} / \text { day (days } 21 \text { to } 25\right)+ \\
\text { Etoposide } 150 \mathrm{mg} / \mathrm{m}^{2} / \text { day (days } 21 \text { to } 23 \text { ) }\end{array}$ & $\begin{array}{l}\text { Local/bifocal germinoma: } \\
40 \text { Gy RT at primary tumour site } \\
\text { Disseminated germinoma: } \\
\text { CSI } 25-30 \text { Gy + } 10 \text { Gy boost on } \\
\text { metastasis }\end{array}$ & $\begin{array}{l}\text { Median FU }=3.5 \text { years } \\
\text { 3-year RFS }=98 \% \\
\text { 3-year EFS }=96.4 \% \\
\text { Recurrence: } 4 \text { ( } 3 \text { in } \\
\text { second complete } \\
\text { remission after salvage } \\
\text { chemotherapy } \pm \text { CSI) }\end{array}$ & $\begin{array}{l}\text { Combination treatment with } \\
\text { chemotherapy and local RT } \\
\text { yielded favourable survival rates } \\
\text { in local and bifocal germinoma }\end{array}$ \\
\hline \multirow{2}{*}{$\begin{array}{c}\text { Sawamura et al. } 1998 \text { [130] } \\
\text { Prospective, multicentre study } \\
12 \text { pure germinomas: } \\
4 \text { pineal, } 2 \text { neurohypophyseal, } 4 \\
\text { multifocal, } 2 \text { disseminated } \\
5 \text {-HCG secreting germinomas: } \\
1 \text { pineal, } 3 \text { neurohypophyseal, } 1 \\
\text { disseminated } \\
\text { Median age }=17 \text { years } \\
16 \text { males, } 1 \text { female }\end{array}$} & $\begin{array}{c}\text { Surgery: } 3 \text { total resections, } 2 \text { subtotal } \\
\text { resections, } 2 \text { partial resections, } 10 \text { biopsies } \\
\text { Local: } 3 / 4 \text { cycles EP: Cisplatin } 20 \mathrm{mg} / \mathrm{m}^{2} / \text { day } \\
+ \text { Etoposide } 100 \mathrm{mg} / \mathrm{m}^{2} / \text { day } \\
5 \text { consecutive days }\end{array}$ & $\begin{array}{l}\text { Local disease: } \\
24 \text { Gy at primary tumour site }\end{array}$ & \multirow{2}{*}{$\begin{array}{l}\text { Median FU }=2 \text { years } \\
2 \text {-year survival } \\
\text { probability }=100 \% \\
16(94 \%) \text { of the } 17 \\
\text { patients were free from } \\
\text { recurrence } \\
1 \text { recurrence-currently } \\
\text { in second complete } \\
\text { remission }\end{array}$} & \multirow{2}{*}{$\begin{array}{l}\text { Chemotherapy (EP and ICE } \\
\text { regimens) followed by reduced } \\
\text { volume and dose RT were } \\
\text { highly effective in obtaining } \\
\text { disease control }\end{array}$} \\
\hline & $\begin{array}{c}\text { Multifocal, disseminated, } \beta \text {-HCG secreting } \\
\text { germinoma: } 3-6 \mathrm{cycles} \text { ICE: } \\
\text { Ifosfamide } 900 \mathrm{mg} / \mathrm{m}^{2} / \text { day+ } \\
\text { Cisplatin } 20 \mathrm{mg} / \mathrm{m}^{2} / \text { day+ } \\
\text { Etoposide } 60 \mathrm{mg} / \mathrm{m}^{2} / \text { day } \\
5 \text { consecutive days } \\
\text { Recurrent disease-same as disseminated }\end{array}$ & $\begin{array}{c}\text { Multifocal disease: } \\
24 \text { Gy at primary tumour site } \\
\text { Disseminated disease: } \\
\text { CSI } 24 \text { Gy }\end{array}$ & & \\
\hline Balmaceda et al. 1996 [109] & \pm Surgery: & \multirow[b]{3}{*}{$\begin{array}{l}\text { RT_-if less than CR after } \\
\text { chemotherapy or } \\
\text { progressive/relapsed disease }\end{array}$} & \multirow[b]{3}{*}{$\begin{array}{l}\text { Median FU: } 2.9 \text { years } \\
\text { CR }=82 \% \\
\text { 2-year OS }=84 \% \\
20 \text { relapses } / 45 \\
\text { germinomas }\end{array}$} & \multirow[b]{3}{*}{$\begin{array}{l}\text { Treatment with chemotherapy } \\
\text { alone is characterized by a high } \\
\text { rate of tumour recurrence }\end{array}$} \\
\hline Prospective study & 18 total resections, 18 partial resections, 33 & & & \\
\hline $\begin{array}{c}45 \text { germinomas out of } 71 \text { ICGCT: } \\
31 \text { pineal, } 21 \text { suprasellar, } 11 \text { bifocal, } 8 \\
\text { other, including } 11 \text { leptomeningeal } \\
\text { disease } \\
\text { Median age = } 12.7 \text { years (out of } 71 \\
\text { ICGCT) }\end{array}$ & $\begin{array}{c}\text { biopsies (out of } 71 \text { ICGCT) } \\
4 \text { cycles of: } \\
\text { Carboplatin } 500 \mathrm{mg} / \mathrm{m}^{2} / \text { day days } 1-2+ \\
\text { Etoposide } 150 \mathrm{mg} / \mathrm{m}^{2} / \text { day days } 1-3+ \\
\text { Bleomycin } 15 \mathrm{mg} / \mathrm{m}^{2} / \text { day day } 3 \\
\text { If CR: } 2 \mathrm{more} \text { cycles }\end{array}$ & & & \\
\hline
\end{tabular}

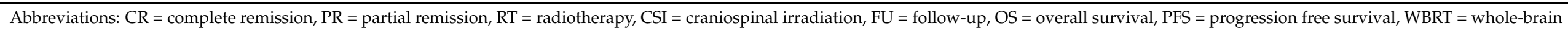

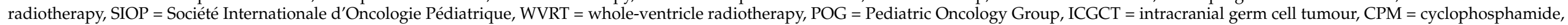

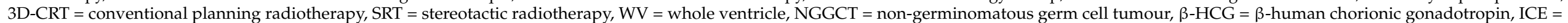

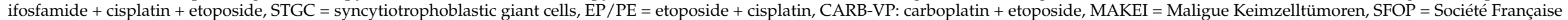
d'Oncologie Pédiatrique, RFS = relapse free survival, EFS = event free survival. 
Moreover, there appears to be a correlation between the ventricles volume and the dose of irradiation received by the healthy brain tissue (at least $12 \mathrm{~Gy}$ ) after WVI and the boost phase of the treatment with IMRT (the smaller the ventricles, the smaller the dose of irradiation of the brain) [131]. Recently, gamma knife radiosurgery has been proposed as an integrated therapy in the management of pineal tumours. As far as germinomas are concerned, stereotactic radiosurgery (SRS) seems to be an effective boost local treatment that warrants the administration of a smaller dose of CSI, in order to minimize the adverse effects in the long-term, as well as a suitable treatment for tumour recurrence. Pineal germinomas treated with SRS alongside with standard adjuvant treatment showed a 20-year local control rate and survival of $80 \%$ [132]. Patients with metastatic pineal germinoma have a bad prognosis, with a $65.8 \%$ rate of long term survival and an increased risk of death represented by diffuse cerebral subarachnoid or leptomeningeal dissemination [26].

The principle of radiotherapy is to irradiate all the tumour cells disseminated in the ventricular system, by covering the cerebrospinal fluid pathway sufficiently. However, whole ventricle and boost irradiation of the tumours situated in the midline structures of the brain also deliver a heavy dose of radiation to the temporal lobes and the hippocampus, structures involved in learning and memory, causing neuropsychological deficits and endocrine dysfunctions [126,129,133-135]. These are frequently encountered in highdose regimens, suggesting that strategies that limit cranial irradiation and the use of simultaneous integrated boost techniques may reduce the adverse effects associated with radiotherapy, having a beneficial impact on the quality of life of the patients [136-139]. A retrospective multi-centre cohort study evaluated the long-term toxicity of the treatment in 112 ICGCT, including 94 germinoma patients. Neurocognitive dysfunction was the most common adverse effect, while suprasellar/hypothalamic tumours and cisplatin treatment were associated with a high risk of hypopituitarism (36.1\%) and ototoxicity (39.2\%) respectively [140]. Hypopituitarism induced by radiotherapy is encountered in $90 \%$ of the cases after radiation treatment of the germinomas located in the neurohypophyseal region, but it also develops after treatment of germinomas located in other sites of the CNS [33]. However, a recent retrospective study, including 49 intracranial germinomas, concluded that hypopituitarism is mainly caused by the tumour and that radiotherapy has no further impairment on the pituitary function [141].

Restoration of endocrine deficiencies has been described in patients treated with chemotherapy alone, suggesting that delaying radiotherapy, especially in young patients with germinomas, may represent a treatment modality [142,143]. With early diagnosis of hypopituitarism and a suitable hormone replacement therapy, most patients achieve an average adult height [21]. Preoperative DI represents a positive predictor factor for the necessity of postoperative long-term hormonal replacement with desmopressin [144]. Secondary malignancies, such as glioblastoma, meningioma, thyroid carcinoma, acute lymphoblastic/myeloid leukaemia, and B-cell lymphoma, have been reported, highlighting the necessity of vigilant follow-up $[145,146]$.

The patient follow-up consists in regular clinical evaluations (neurologic, endocrine, visual, and hearing assessments), tumour markers (serum and/or CSF AFP and $\beta-H C G$ ), and MRI scans. Tumour markers and imaging examinations should be evaluated simultaneously, since the diagnosis of relapsed disease can be established either on the presence of elevated markers or on the appearance of a new lesion [129,147]. Currently, there is no consensus regarding the superior sensitivity between serum and CSF markers. Initial evaluation shall be carried out 1-2 months after treatment completion and every 4-6 months thereafter, for the first $2-5$ years, followed by annual assessments $[51,76,148,149]$.

\section{Future Perspectives}

Ongoing molecular research aims to shed light upon germinoma's underlying genomic and epigenetic mechanisms and their impact on the tumour evolution and treatment response. In this regard, molecular targeted therapy, such as selective tyrosine kinase inhibitors (TKI), may achieve promising results in cases of intracranial germinomas pre- 
senting KIT mutations that are resistant to standard CRT. Treatment with TKI has been proposed, considering their efficiency in cases of gastrointestinal stromal tumours (GIST) harbouring KIT mutations. Imatinib, a selective TKI, showed efficacy in cases of GISTs resistant to conventional treatment that presented exon 9 and 11 mutation [150]. Similarly, in CNS germinomas, KIT exons 11 and 17 are most frequently mutated, followed by exons $[2,10,13,14,87,89,90,92]$. Therefore, it can be presumed that germinomas harbouring exon 11 mutations are candidates for Imatinib therapy. KIT mutation V560D (Val560Asp), reported in one case of CNS germinoma, is likely to respond to Imatinib, as was previously reported in cases of GIST and mastocytosis harbouring the same mutation [89]. Ripretinib, another KIT inhibitor, is effective in cases of Imatinib resistant GISTs presenting D816V (Asp816Val), a mutation in exon 17 also encountered in CNS germinomas [151]. Furthermore, Dasatinib, a tyrosine kinase inhibitor (TKI) that crosses the blood-brain barrier, was evaluated in a retrospective review including five patients with CNS pure germinomas. However, despite the multimodal treatment, four patients finally experienced disease progression, and the efficacy of Dasatinib was not demonstrated [152]. Nevertheless, an ongoing phase I/II trial (NCT00788125) evaluates the treatment response to Dasatinib in combination with Ifosfamide, Carboplatin, and Etoposide of various tumours, including extragonadal germ cell tumours [153].

Other therapeutic options include MAPK and AKT/mTOR inhibitors. Ichimura et al. evaluated on cell cultures the effect of pp242 (Torkinib), an inhibitor of both MTOR complexes (mTORC1 and $m$ TORC2), on two germinoma MTOR mutations (M2327I and L2334V). They discovered that Torkinib inhibits in a dose-dependent manner the phosphorylation, cell migration, and growth induced by the mutated MTOR [88]. These results confirm that the mutations analysed are pathogenic and suggest that Torkinib warrants further evaluation as a potential targeted molecular agent in resistant CNS germinomas. Targeted inhibition of $R A S / M A P K$ pathway may play a role in recurrent or resistant tumours and warrants further investigation.

Immune checkpoint blockade, with PD-1/PDL-1 inhibitors (Nivolumab, Pembrolizum$\mathrm{ab}$, Atezolizumab, Durvalumab), represents another potential alternative therapy for resistant cases, considering the presence of a large immune infiltrate and the reported high expressions of PD-1 and PD-L1. Zschäbitz et al. reported a partial response after 15 cycles of Pembrolizumab in a patient with metastatic pituitary germinoma that did not respond to Sunitinib and second-line chemotherapy [154]. A phase II study is currently recruiting patients to evaluate the response of resistant pineal germinomas to Durvalumab (PD-L1 inhibitor) in combination with Tremelimumab (CTLA-4 inhibitor) [155].

In order to select the most appropriate course of treatment, the patients require a personalized management. Relapsed/resistant cases may be enrolled in clinical trials evaluating targeted therapies in CNS germinomas. They should also benefit from genetic and immunological testing, to discover whether they present pathogenic mutations or express immunological markers. Based on these results, the patient may receive the appropriate treatment, in accordance with each genotype (tyrosine kinase inhibitors / MTOR inhibitors/immune checkpoint blockade). Considering the young age of the patients and the radiation side effects, it is also important to offer the best quality of life possible. In this regard, association between targeted therapy and standard CRT may permit dose reduction or even RT elimination.

\section{Conclusions}

Intracranial germinomas are rare tumours mainly affecting the paediatric population. Although CRT has favourable results, research has been carried out in the endeavour to minimize the RT dosage and field, to provide the best quality of life for these patients. Nevertheless, resistant/relapsed tumours are therapeutically challenging. These cases may require genetic and immunological testing to identify patients that may benefit from personalized targeted therapy. Ongoing clinical trials aim to evaluate the efficiency of molecular targeted therapy in these cases. 
Author Contributions: C.I., C.E.G., H.S. and C.A.S. performed data research, analysis of the data, drafted the initial article, and edited this review. C.G. performed histological analysis. A.I.C. and S.D.N. performed clinical and radiological data analysis. C.I. created the figures in the article. C.A.S. added critical revisions to the article. All authors have read and agreed to the published version of the manuscript.

Funding: This research received no external funding.

Informed Consent Statement: To publish this paper, written informed consent has been obtained from the participating patient (whose histological and imaging MRI images were presented as examples in this article).

Conflicts of Interest: The authors declare no conflict of interest. 


\section{Appendix A}

Table A1. Retrospective studies regarding treatment regimes in CNS germinomas.

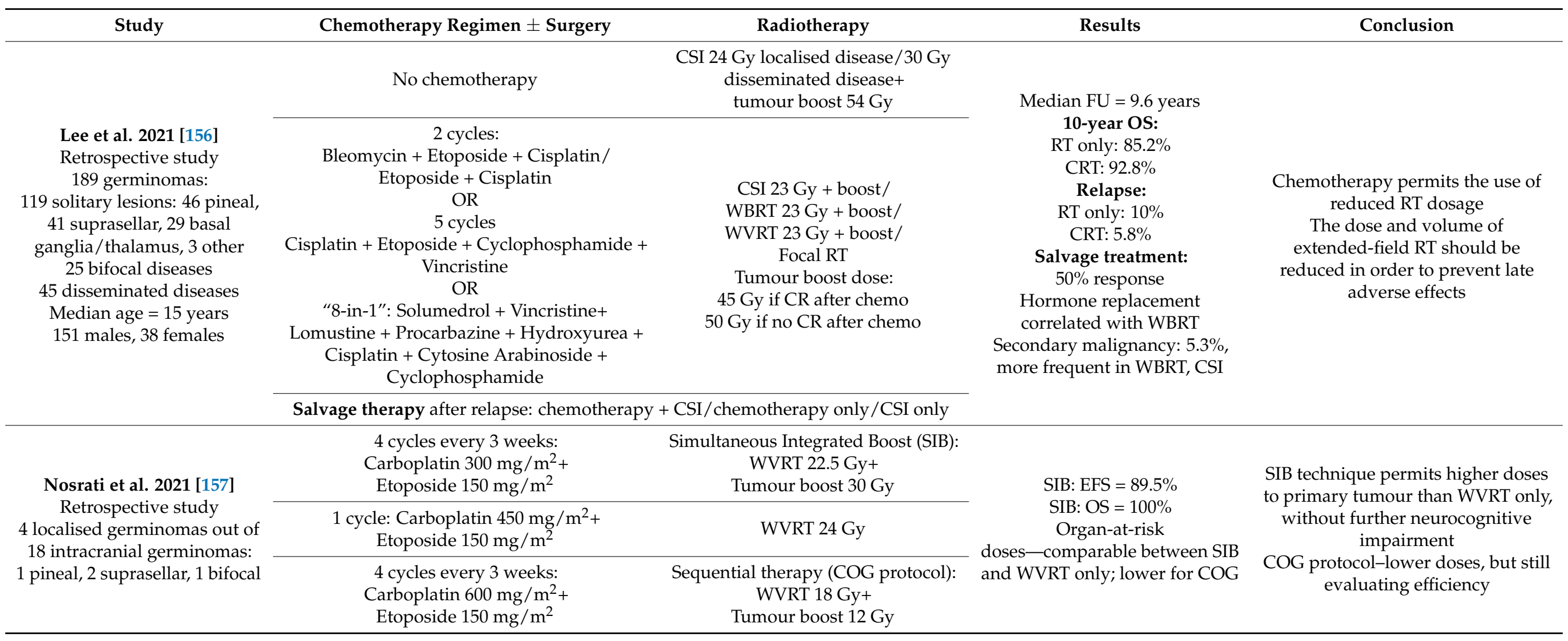


Table A1. Cont.

\begin{tabular}{|c|c|c|c|c|}
\hline Study & Chemotherapy Regimen \pm Surgery & Radiotherapy & Results & Conclusion \\
\hline \multirow{2}{*}{$\begin{array}{c}\text { Baroni et al. } 2021 \text { [148] } \\
\text { Retrospective study } \\
39 \text { germinomas: } \\
15 \text { pineal, } 9 \text { sellar / suprasellar, } \\
7 \text { bifocal, } 2 \text { thalamus/basal } \\
\text { ganglia, } 1 \text { other, } \\
5 \text { disseminated cases } \\
\text { Median age }=12.1 \text { years } \\
27 \text { males, } 12 \text { females }\end{array}$} & $\begin{array}{c}\text { Surgery: } 1 \text { complete resection, } 6 \text { partial } \\
\text { resections, } 32 \text { biopsies } \\
2 \text { courses of: } \\
\text { Carboplatin + Etoposide } \\
\text { alternating with } \\
\text { Ifosfamide + Etoposide }\end{array}$ & $\begin{array}{l}\text { FR/ } \\
\text { FR + WVRT } / \\
\text { CSI only (1 patient) }\end{array}$ & $\begin{array}{c}\text { Median FU }=6.5 \text { years } \\
\text { 5-year PFS }=83.5 \% \\
\text { 5-year OS }=88.7 \% \\
\text { 5-year PFS: } \\
\text { FR: } 63 \% \\
\text { FR + WVRT: } 94 \% \\
\text { 4 deaths }\end{array}$ & \multirow[t]{2}{*}{$\begin{array}{l}\text { FR increases the risk of recurrence } \\
\text { Chemotherapy and focal RT + } \\
\text { WVRT has favourable results in } \\
\text { localized germinomas }\end{array}$} \\
\hline & \multicolumn{2}{|c|}{$\begin{array}{l}\text { 1st line salvage therapy: Platinum-based chemotherapy + CSI } \pm \text { FR } \\
\text { 2nd line salvage therapy: } 4 \text { cycles: Gemcitabine-Paclitaxel-Oxaliplatin }+\mathrm{HDC}+ \\
\text { stem cell rescue }\end{array}$} & $\begin{array}{c}7 \text { localized germinoma relapsed } \\
(5 \text { treated with FR/2 with FR + } \\
\text { WVRT) }\end{array}$ & \\
\hline $\begin{array}{c}\text { Li et al. } 2021 \text { [147] } \\
\text { Retrospective study } \\
161 \text { basal ganglia germinomas: } \\
68 \text { right, } 66 \text { left, } 15 \text { bilateral, } 12 \\
\text { basal ganglia + sellar } \\
\text { Median age }=12 \text { years } \\
150 \text { males, } 11 \text { females }\end{array}$ & $\begin{array}{c}2 \text { cycles every } 4 \text { weeks before and after RT: } \\
\text { Ifosfamide, } 1.5 \mathrm{~g} / \mathrm{m}^{2} \text { days } 1-3+ \\
\text { Etoposide, } 70 \mathrm{mg} / \mathrm{m}^{2} \text { days } 1-3+ \\
\text { Cisplatin, } 30 \mathrm{mg} / \mathrm{m}^{2} \text { days } 1-3 \\
\pm \text { Surgery: } 15 \text { resection, } 15 \text { biopsies }\end{array}$ & $\begin{array}{l}\text { FR/CSI (30 Gy) + tumour boost (10 } \\
\text { Gy)/ } \\
\text { WBRT (30 Gy) + tumour boost }(10 \\
\text { Gy) }\end{array}$ & $\begin{array}{c}\text { Median FU }=6.9 \text { years } \\
5 \text {-year DFS }=92 \% \\
5 \text {-year OS FR }=94.1 \% \\
\text { 5-year OS WBRT }=97.2 \% \\
\text { 5-year OS CSI }=100 \%\end{array}$ & $\begin{array}{l}\text { WBRT offers a better quality of life } \\
\text { compared to CSI and represents an } \\
\text { optimal treatment strategy in } \\
\text { localized basal ganglia germinomas }\end{array}$ \\
\hline $\begin{array}{l}\text { Rajagopal et al. } 2021 \text { [158] } \\
\text { Retrospective study } \\
16 \text { germinomas: } 6 \text { pineal, } 6 \\
\text { suprasellar, } 1 \text { bifocal, } 2 \text { basal } \\
\text { ganglia, } 1 \text { other, including } 7 \\
\text { disseminated cases } \\
\text { Median age }=11 \text { years } \\
11 \text { males, } 5 \text { females }\end{array}$ & $\begin{array}{c} \pm \text { Surgery: } 1 \text { total resection, } 3 \text { subtotal } \\
\text { resection, } 12 \text { biopsies, } 3 \text { ventriculoperitoneal } \\
\text { shunts, } 3 \text { ventriculostomies } \\
\text { SIOP CNS GCT } 96 \text { protocol/ } \\
\text { SIOP CNS GCT II protocol/ } \\
\text { physician preference }\end{array}$ & $\begin{array}{c}\text { CSI (24-25 Gy) } \pm \text { boost (40-44.4 } \\
\text { Gy)/ } \\
\text { WVRT (24-36 Gy) + boost (36-54 } \\
\text { Gy)/ } \\
\text { Local RT (40-50 Gy) } \\
\text { Recurrence: Chemo + CSI } 24 \text { Gy + } \\
\text { cranial RT } 19.8 \text { Gy }\end{array}$ & $\begin{array}{l}\text { Median FU }=3.5 \text { years } \\
10 \text {-year OS }=75.5 \% \\
10 \text {-year EFS }=61.1 \% \\
\text { Recurrence: } 5 \text { patients }\end{array}$ & $\begin{array}{l}\text { Inferior results are observed in } \\
\text { underdeveloped countries due to } \\
\text { late diagnosis, poor compliance, } \\
\text { suboptimal treatment, and } \\
\text { complications of therapy }\end{array}$ \\
\hline
\end{tabular}


Table A1. Cont.

\begin{tabular}{|c|c|c|c|c|}
\hline Study & Chemotherapy Regimen \pm Surgery & Radiotherapy & Results & Conclusion \\
\hline $\begin{array}{c}\text { Hong et al. } 2020 \text { [146] } \\
\text { Retrospective study } \\
66 \text { germinomas + normal } \\
\text { tumour markers out of } 69 \\
\text { low-risk tumours: } 24 \text { pineal, } \\
14 \text { sellar/suprasellar, } 17 \\
\text { thalamus/basal ganglia, } 10 \\
\text { bifocal, } 4 \text { other, including } 7 \\
\text { disseminated cases } \\
\text { Median age }=11.8 \text { years } \\
55 \text { males, } 16 \text { females }\end{array}$ & $\begin{array}{c} \pm \text { Surgery: resection/biopsy/endoscopic } \\
\text { third ventriculostomy/extraventricular } \\
\text { drainage/ventriculoperitoneal shunt } \\
\text { Carboplatin } 450 \mathrm{mg} / \mathrm{m}^{2} / \text { day+ } \\
\text { Etoposide } 100 \mathrm{mg} / \mathrm{m}^{2} / \text { day } \\
\text { Alternating with } \\
\text { Cyclophosphamide } 1000 \mathrm{mg} / \mathrm{m}^{2} / \text { day+ } \\
\text { Etoposide } 150 \mathrm{mg} / \mathrm{m}^{2} / \text { day }\end{array}$ & $\begin{array}{c}\text { Local RT (40.4 Gy)/ } \\
\text { WVRT (19.8 Gy)/ } \\
\text { WBRT (30.6 Gy)/ } \\
\text { CSI (23.4Gy)—multifocal/metastatic } \\
\text { disease, poor response to } \\
\text { chemotherapy }\end{array}$ & $\begin{array}{c}\text { Median FU }=8.4 \text { years } \\
\text { 10-year EFS }=88.6 \% \\
10 \text {-year OS }=98.3 \% \\
\text { 10-year relapse incidence }=9.3 \% \\
4 \text { basal ganglia germinoma } \\
\text { relapsed } \\
\text { Endocrine complications: } 53.6 \%\end{array}$ & $\begin{array}{l}\text { Chemo-radiotherapy achieved } \\
\text { favourable results }\end{array}$ \\
\hline $\begin{array}{l}14 \text { germinomas }+ \text { high tumour } \\
\text { markers out of } 58 \text { high-risk } \\
\text { tumours: } 28 \text { pineal, } 13 \\
\text { sellar } / \text { suprasellar, } 7 \\
\text { thalamus/basal ganglia, } 7 \\
\text { bifocal, } 3 \text { other, including } 7 \\
\text { disseminated cases } \\
\text { Median age }=12.2 \text { years } \\
47 \text { males, } 11 \text { females }\end{array}$ & $\begin{array}{c}\text { Carboplatin } 450 \mathrm{mg} / \mathrm{m}^{2} / \text { day+ } \\
\text { Etoposide } 150 \mathrm{mg} / \mathrm{m}^{2} / \text { day } \\
\text { Bleomycin } 15 \mathrm{mg} / \mathrm{m}^{2} / \text { day } \\
\text { Alternating with } \\
\text { Cyclophosphamide } 2000 \mathrm{mg} / \mathrm{m}^{2} / \text { day+ } \\
\text { Etoposide } 150 \mathrm{mg} / \mathrm{m}^{2} / \text { day+ } \\
\text { Bleomycin } 15 \mathrm{mg} / \mathrm{m}^{2} / \text { day }\end{array}$ & $\begin{array}{l}\text { WVRT (23.4 Gy)/ } \\
\text { WBRT (30.6 Gy)/ } \\
\text { CSI (23.4 Gy) }\end{array}$ & $\begin{array}{c}\text { Median FU }=8.3 \text { years } \\
\text { 10-year EFS }=100 \% \\
\text { 10-year OS }=100 \% \\
\text { 10-year relapse incidence }=5.6 \% \\
\text { Endocrine complications: } 53.4 \%\end{array}$ & $\begin{array}{l}\text { Germinoma with elevated tumour } \\
\text { markers could benefit from a lower } \\
\text { intensity treatment }\end{array}$ \\
\hline $\begin{array}{c}\text { Chou et al. } 2020 \text { [159] } \\
\text { Retrospective study } \\
24 \text { germinomas: } 17 \text { pineal, } 13 \\
\text { suprasellar, } 7 \text { periventricular, } 2 \\
\text { basal ganglia } \\
13 \text { isolated tumours } \\
11 \text { multifocal tumours } \\
5 \beta \text {-hCG-secreting } \\
\text { germinomas } \\
\text { Median age }=14.1 \text { years } \\
20 \text { males, } 4 \text { females }\end{array}$ & $\begin{array}{c}\text { Surgery: } 1 \text { total resection, } 9 \text { subtotal } \\
\text { resections, } 14 \text { biopsies } \\
\text { Short-course neoadjuvant chemotherapy: } \\
2 \text { courses of } \\
\text { Cisplatin } 20 \mathrm{mg} / \mathrm{m}^{2}+ \\
\text { Etoposide } 40 \text { or } 100 \mathrm{mg} / \mathrm{m}^{2} \text { for } 5 \text { days }\end{array}$ & $\begin{array}{c}\text { WVRT/WBRT ( } 23.4 \mathrm{~Gy}) \text { without } \\
\text { local boost }\end{array}$ & $\begin{array}{c}\text { Median FU }=8.8 \text { years } \\
100 \% \text { complete remission } \\
5 \text {-year DFS } \beta \text {-hCG-secreting } \\
\text { germinomas }=60 \% \\
5 \text {-year DFS normal } \beta \text {-hCG level } \\
\text { germinomas }=100 \%\end{array}$ & $\begin{array}{l}\text { CNS germinoma patients with } \\
\text { normal } \beta \text {-hCG levels may benefit } \\
\text { from short course chemotherapy } \\
\text { and low dose RT without local boost }\end{array}$ \\
\hline
\end{tabular}


Table A1. Cont.

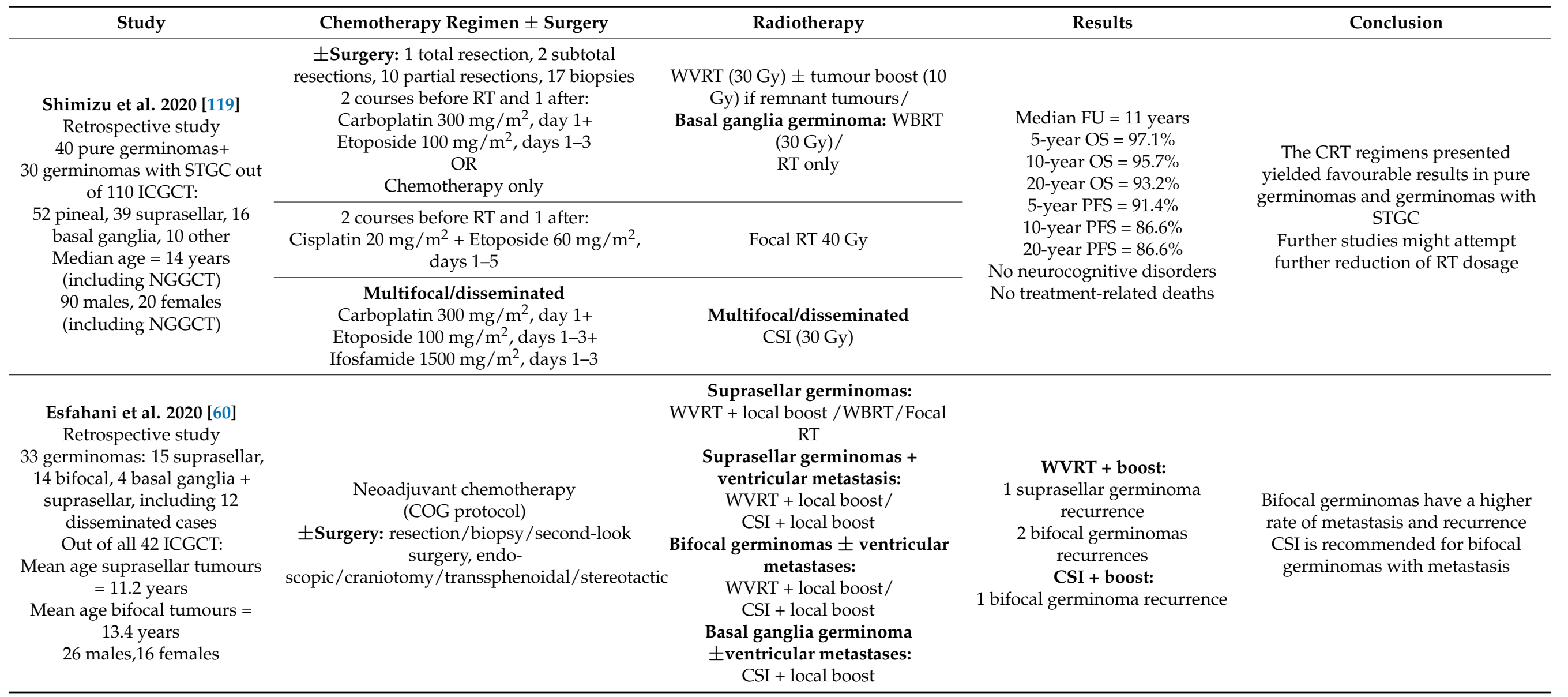


Table A1. Cont.

\begin{tabular}{|c|c|c|c|c|}
\hline Study & Chemotherapy Regimen \pm Surgery & Radiotherapy & Results & Conclusion \\
\hline $\begin{array}{c}\text { Li et al. } 2020 \text { [160] } \\
\text { Retrospective study } \\
49 \text { non-metastatic bifocal } \\
\text { germinomas: } \\
34 \text { sellar/suprasellar + pineal, } \\
15 \text { sellar/suprasellar }+ \\
\text { thalamus/basal ganglia } \\
\text { Median age }=13 \text { years } \\
34 \text { males, } 15 \text { females }\end{array}$ & $\begin{array}{l}\text { Two courses before and after RT: } \\
\text { Ifosfamide } 1.5 \mathrm{~g} / \mathrm{m}^{2} \text { days } 1-3+ \\
\text { Etoposide } 70 \mathrm{mg} / \mathrm{m}^{2} \text { days } 1-3+ \\
\text { Cisplatin } 30 \mathrm{mg} / \mathrm{m}^{2} \text { days } 1-3 \\
\pm \text { Surgery }\end{array}$ & $\begin{array}{l}\text { CSI }+ \text { boost } / \\
\text { WBRT }+ \text { boost } / \\
\text { Focal RT }\end{array}$ & $\begin{array}{c}\text { Median FU }=4.3 \text { years } \\
5 \text {-year DFS }=96.7 \% \\
5 \text {-year OS }=97.3 \% \\
\text { WBRT_comparable disease-free } \\
\text { survival with CSI }\end{array}$ & \multirow[t]{2}{*}{$\begin{array}{l}\text { Limited field RT could replace CSI } \\
\text { in patients with non-metastatic } \\
\text { bifocal germinoma }\end{array}$} \\
\hline $\begin{array}{c}81 \text { non-metastatic } \\
\text { bifocal germinoma } \\
\text { (literature): sellar/suprasellar } \\
\text { + pineal }\end{array}$ & Not mentioned & Focal RT/WVRT/WBRT/CSI & $\begin{array}{l}\text { No difference regarding the } \\
\text { disease-free survival }\end{array}$ & \\
\hline \multirow{4}{*}{$\begin{array}{c}\text { Takada et al. } 2018 \text { [161] } \\
\text { Retrospective study } \\
6 \text { germinomas }+ \\
12 \text { germinomas with STGC, } \\
\text { out of } 24 \text { ICGCT: } \\
10 \text { pineal, } 3 \text { suprasellar, } 6 \text { basal } \\
\text { ganglia/brainstem, } 5 \\
\text { multifocal, } 4 \text { disseminated } \\
\text { cases } \\
\text { Median age = } 13 \text { years } \\
\text { (including NGGCT) } \\
20 \text { males, } 4 \text { females (including } \\
\text { NGGCT) }\end{array}$} & $\begin{array}{c}\text { Pure germinoma } \\
\pm \text { Surgery: } 2 \text { partial excisions, } 2 \text { biopsies } \\
2-5 \text { courses of conventional dose therapy } \\
\text { (CDC): ICE: Ifosfamide + Cisplatin + } \\
\text { Etoposide }\end{array}$ & WVRT 24 Gy & $\begin{array}{c}\text { Median follow-up }=9.3 \text { years } \\
10 \text {-year OS }=100 \% \\
1 \text { recurrence after } 10 \text { years }\end{array}$ & \multirow{4}{*}{$\begin{array}{l}\text { Favourable results obtained with } \\
\text { combined treatment: chemotherapy } \\
\text { (conventional/intensive) and } \\
\text { reduced field and dose irradiation }\end{array}$} \\
\hline & $\begin{array}{c}\text { Germinoma with STGC: } \\
\pm \text { Surgery: } 1 \text { total excision, } 3 \text { partial } \\
\text { excisions, } 4 \text { biopsies } \\
2 / 3 \text { courses of CDC and high-dose } \\
\text { chemotherapy (HDC) + PBSCT } \\
\text { HDC: PEB/EP/CARE/ICE }\end{array}$ & $\begin{array}{l}\text { WVRT/larger field 24-30 Gy } \\
\qquad \pm \\
\text { local boost irradiation (20 Gy) }\end{array}$ & $\begin{array}{c}3 \text { patients relapsed and died of } \\
\text { their disease } \\
\text { 10-year OS }=78.7 \%\end{array}$ & \\
\hline & No chemotherapy & $\begin{array}{c}\text { CSI } 24 \mathrm{~Gy}+\text { primary tumour site } \\
\text { boost } 16 \mathrm{~Gy}\end{array}$ & $\begin{array}{c}\text { 5-year PFS }=97 \% \\
\text { OS }=95 \% \\
4 \text { recurrences at original site }\end{array}$ & \\
\hline & $\begin{array}{c}\text { Disseminated disease } \\
\pm \text { Chemotherapy (same regimen) }\end{array}$ & $\begin{array}{c}\text { Disseminated disease } \\
24 \text { Gy CSI + } 16 \text { Gy boost at primary } \\
\text { tumour site and metastases }\end{array}$ & $\begin{array}{c}5 \text {-year PFS }=100 \% \\
\text { OS }=98 \%\end{array}$ & \\
\hline
\end{tabular}


Table A1. Cont.

\begin{tabular}{|c|c|c|c|c|}
\hline Study & Chemotherapy Regimen \pm Surgery & Radiotherapy & Results & Conclusion \\
\hline $\begin{array}{c}\text { Cheng et al. } 2016 \text { [138] } \\
\text { Retrospective study } \\
24 \text { germinomas: } \\
9 \text { suprasellar, } 6 \text { pineal, } 8 \\
\text { bifocal, } 1 \text { basal ganglia, } \\
\text { including } 4 \text { disseminated cases } \\
\text { Median age = } 13.3 \text { years } \\
13 \text { males, } 11 \text { females }\end{array}$ & $\begin{array}{c}\text { 土Surgery: biopsy, external ventricular drain, } \\
\text { septostomy, ventriculostomy, } \\
\text { ventricular-peritoneal shunt } \\
2 \text { cycles of } \\
\text { Carboplatin } 600 \mathrm{mg} / \mathrm{m}^{2}+\text { Etoposide } 300 \\
\mathrm{mg} / \mathrm{m}^{2} \\
\text { alternating with } \\
\text { mg/m } / \mathrm{m}^{2} \\
\text { OR } \\
3-4 \text { cycles } \\
\text { Ifosfamide } 9000 \mathrm{mg} / \mathrm{m}^{2}+\text { toposide } 300 \\
\text { Carboplatin } 600 \mathrm{mg} / \mathrm{m}^{2}+\text { Etoposide } 450 \\
\mathrm{mg} / \mathrm{m}^{2} 3-4 \text { cycles }\end{array}$ & $\begin{array}{c}\text { WVRT (23.4-24 Gy)/ } \\
\text { WVRT (23.4-24 Gy) + boost (16 Gy)/ } \\
\text { WBRT (23.4 Gy)/ } \\
\text { Focal RT ( } 40 \text { Gy)/ } \\
\text { CSI (23.4 Gy) }\end{array}$ & $\begin{array}{c}\text { Median FU }=5 \text { years } \\
5 \text {-year PFS }=96 \% \\
5 \text {-year OS }=100 \% \\
1 \text { recurrence } \\
\text { No difference in neurocognitive } \\
\text { functions between focal RT and } \\
\text { WVRT }\end{array}$ & $\begin{array}{c}\text { Successful results in the setting of } \\
\text { CRT, with reduces dose and volume } \\
\text { RT } \\
\text { No relapses in cases of WVRT } \\
\text { without boost }\end{array}$ \\
\hline $\begin{array}{l}\text { Weksberg et al. } 2012 \text { [162] } \\
\text { Retrospective study } \\
20 \text { bifocal germinomas (pineal } \\
\text { + suprasellar), including } \\
11 \text { disseminated diseases } \\
\text { Median age }=19 \text { years } \\
19 \text { males, } 1 \text { female }\end{array}$ & $\begin{array}{c} \pm \text { Surgery: } 13 \text { biopsies } \\
\pm \text { Neoadjuvant platinum-based } \\
\text { chemotherapy+ } \\
\text { Etoposide } \pm \\
\text { Ifosfamide } \\
\text { Chemotherapy was not administered to } \\
\text { patients who received CSI }\end{array}$ & $\begin{array}{l}\text { Median RT dose = 50 Gy } \\
\text { Localized disease: } \\
\text { CSI/WBRT/WVI/local RT } \\
\text { Disseminated disease: } \\
\text { CSI/WBRT/WVRT }\end{array}$ & $\begin{array}{c}\text { Median FU = } 8.2 \text { year } \\
5 \text {-year PFS }=100 \%\end{array}$ & \multirow{3}{*}{$\begin{array}{l}\text { Bifocal germinomas with no signs of } \\
\text { dissemination are candidates for } \\
\text { neoadjuvant chemotherapy and } \\
\text { spinal sparing RT. } \\
\text { CSI represents the treatment of } \\
\text { choice for disseminated disease. }\end{array}$} \\
\hline $\begin{array}{l}60 \text { bifocal (pineal }+ \\
\text { suprasellar) germinomas } \\
\text { (literature) including } \\
14 \text { disseminated diseases } \\
\text { Age range: } 6-30 \text { years } \\
43 \text { males, } 11 \text { females, } 6 \text { not } \\
\text { stated }\end{array}$ & $\begin{array}{c} \pm \text { Neoadjuvant platinum-based } \\
\text { chemotherapy }+ \\
\text { Etoposide } \pm \\
\text { Ifosfamide/Methotrexate }\end{array}$ & $\begin{array}{l}\text { Median RT dose = } 40 \text { Gy } \\
\text { CSI/WBRT/WVI/local RT }\end{array}$ & $\begin{array}{l}\text { Median FU = } 5 \text { years } \\
5 \text {-year PFS }=87 \%\end{array}$ & \\
\hline $\begin{array}{c}\text { Combined analysis: } \\
80 \text { bifocal germinoma (pineal+ } \\
\text { suprasellar), including } 25 \\
\text { disseminated cases } \\
62 \text { males, } 12 \text { females, } 6 \text { not } \\
\text { stated } \\
\text { Age range: } 6-33 \text { years }\end{array}$ & $\begin{array}{c}\text { 55 localized diseases: } \\
5 \text {-year PFS }=95 \% \\
5 \text {-year PFS (CSI) }=100 \% \\
5 \text {-year PFS (WBRT /WVI /local RT) }=88 \% \\
\text { 5-year PFS (WBRT } / \text { WVI /local RT + Chemo) } \\
=96 \%\end{array}$ & $\begin{array}{r}25 \text { disseminat } \\
\text { 5-year PFS } \\
5 \text {-year PFS (C } \\
\text { 5-year PFS (WBRT/WVI / lc }\end{array}$ & $\begin{array}{l}\text { d disease: } \\
=80 \% \\
\mathrm{SI}=100 \% \\
\text { cal } \mathrm{RT}+\text { Chemo) }=69 \%\end{array}$ & \\
\hline
\end{tabular}


Table A1. Cont.

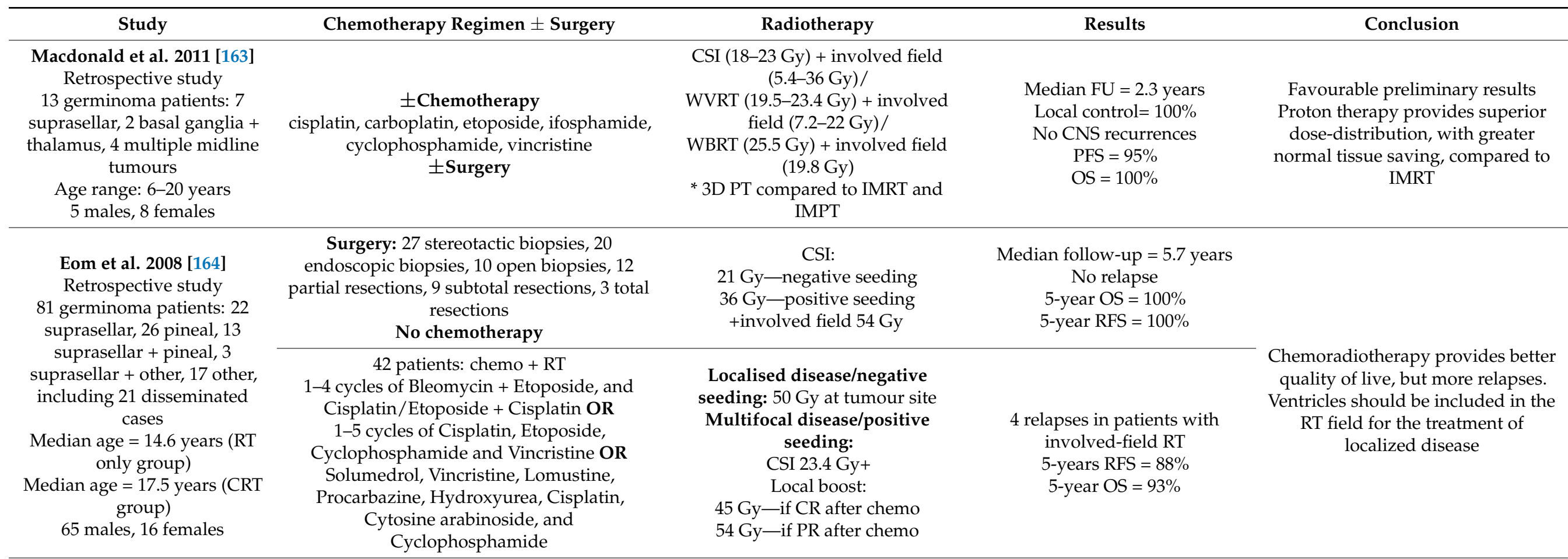

\section{Lafay-Cousin et al. 2006 [23]}

Retrospective

6 patients with bifocal germinomas out of 17 germinomas:

4 pineal + suprasellar,

1 pineal + third ventricle floor,

1 pineal + tuber cinereum

Median age $=12.8$ years

5 males, 1 female \pm Surgery: 3 third ventricle

ventriculostomies + biopsies

$3 / 4$ cycles of Etoposide + Cisplatin OR

2 courses of Carboplatin + Etoposide alternating with

2 courses of Ifosfamide + Etoposide
WVRT 24-40 Gy

\pm boost at both tumour sites (16 Gy)
Median $\mathrm{FU}=4$ years

$$
\mathrm{CR}=100 \%
$$

No persistent disease/recurrence
Bifocal germinoma (pineal + suprasellar) can be treated as locoregional disease with chemotherapy and limited field radiation (WVRT \pm boost) 
Table A1. Cont.

\begin{tabular}{|c|c|c|c|c|}
\hline Study & Chemotherapy Regimen \pm Surgery & Radiotherapy & Results & Conclusion \\
\hline $\begin{array}{c}\text { Modak et al. 2004 [165] } \\
\text { Retrospective } \\
9 \text { patients with relapsed } \\
\text { germinoma out of } 21 \text { CNS } \\
\text { relapsed GCT: } \\
3 \text { intracranial, } 1 \text { spinal cord, } 1 \\
\text { intracranial + spinal cord, } 1 \\
\text { ventricular, } 1 \text { pineal + } \\
\text { abdominal, } 1 \text { pineal + lateral } \\
\text { horn, } 1 \text { leptomeningeal } \\
\text { dissemination } \\
\text { Age range: } 7-31 \text { years } \\
7 \text { males, } 2 \text { females }\end{array}$ & $\begin{array}{c}\text { } \pm \text { Surgery: } 4 \text { biopsies } \\
\text { Thiotepa } 200 \mathrm{mg} / \mathrm{m}^{2} / \mathrm{d} \text { for } 3 \text { days with } \\
\text { ASCR; followed } 4 \text { weeks later by Thiotepa } \\
200 \mathrm{mg} / \mathrm{m}^{2} / \mathrm{d} \text { for } 3 \text { days with ASCR } \\
\text { Or } \\
\text { Carboplatin } 500 \mathrm{mg} / \mathrm{m}^{2} / \mathrm{d} \text { on days } 1-3 \\
\text { +Thiotepa } 300 \mathrm{mg} / \mathrm{m}^{2} / \mathrm{d} \text { on days } 4-6 \\
\text { +Etoposide } 250 \mathrm{mg} / \mathrm{m}^{2} / \mathrm{d} \text { on days } 4-6 \\
\text { Or } \\
\text { Carboplatin } 500 \mathrm{mg} / \mathrm{m}^{2} / \mathrm{d} \text { on days } 1-3 \\
\text { +Thiotepa } 300 \mathrm{mg} / \mathrm{m}^{2} / \mathrm{d} \text { on days } 4-6 \\
\text { +Temozolomide } 150-250 \mathrm{mg} / \mathrm{m}^{2} / \mathrm{d}\end{array}$ & $\begin{array}{l}\text { Post-chemotherapy adjuvant RT: } \\
\text { - cranial irradiation } \\
\text {-CSI } \pm \text { focal irradiation }\end{array}$ & $\begin{array}{c}\text { Median } \mathrm{FU}=4 \text { years } \\
\text { OS }=78 \% \\
\text { PFS }=78 \% \\
2 \text { deaths: } \\
-1 \text { progressive disease }(\mathrm{PD}) \\
-1 \text { pulmonary fibrosis } \\
\text { secondary to bleomycin and } \\
\text { spinal irradiation }\end{array}$ & $\begin{array}{l}\text { High dose chemotherapy followed } \\
\text { by ASCR represents an effective } \\
\text { alternative therapy for patients with } \\
\text { relapsed CNS germinomas }\end{array}$ \\
\hline $\begin{array}{c}\text { Haas-Kogan et al. } 2003 \text { [166] } \\
\text { Retrospective } \\
49 \text { germinomas: } \\
41 \text { localized } \\
8 \text { disseminated } \\
\text { Median age }=15 \text { years } \\
32 \text { males, } 17 \text { females }\end{array}$ & $\begin{array}{c} \pm \text { Surgery: } 22 \text { biopsies, } 19 \text { subtotal resections, } \\
5 \text { total resections } \\
\pm \text { Chemotherapy }\end{array}$ & $\begin{array}{c}\text { Localised disease: } \\
\text { CSI/WBRT/WVRT }(32.4 \mathrm{~Gy})+\text { local } \\
\text { boost/Local RT } \\
\text { Disseminated disease: } \\
\text { CSI }\end{array}$ & $\begin{array}{l}\text { Median FU }=7.5 \text { years } \\
5 \text {-year OS }=93 \% \\
\text { 5-year PFS }=88 \% \\
5 \text { relapses } \\
2 \text { deaths }\end{array}$ & $\begin{array}{l}\text { CSI is not necessary for localized } \\
\text { disease; } \\
\text { WVRT + local boost (total of } 45-50 \\
\text { Gy) is recommended in localized } \\
\text { disease }\end{array}$ \\
\hline $\begin{array}{c}\text { Fouladi et al, } 1998 \text { [167] } \\
\text { Retrospective study } \\
16 \text { germinomas: } 6 \text { pineal, } 3 \\
\text { suprasellar, } 3 \text { bifocal, } 4 \\
\text { metastatic } \\
\text { Median age: } 11.5 \text { years (RT } \\
\text { only group) } \\
\text { Median age }=10.8 \text { years (CRT } \\
\text { group) } \\
13 \text { males, } 3 \text { females }\end{array}$ & $\begin{array}{c}\begin{array}{c}\text { Surgery: } 16 \text { biopsies } \\
\text { No chemotherapy }\end{array} \\
2-3 \text { cycles every } 4 \text { weeks: } \\
\left.\text { Cisplatin } 20 \mathrm{mg} / \mathrm{m}^{2} / \text { day (days } 1-5\right)+ \\
\left.\text { Etoposide } 120 \mathrm{mg} / \mathrm{m}^{2} / \text { day (days } 1-5\right) \pm \\
\left.\text { Bleomycin } 15 \mathrm{mg} / \mathrm{m}^{2} \text { (days } 1,8,15\right) \\
\text { OR Carboplatin + Etoposide + Ifosfamide } \\
\text { OR Cisplatin + Etoposide + } \\
\text { Cyclophosphamide }\end{array}$ & $\begin{array}{c}\text { Local/metastatic disease: } \\
\text { CSI 24-35 Gy (median dose } 25 \text { Gy) + } \\
\text { tumour boost 15-30.6 Gy (median } \\
\text { dose 15.5 Gy) } \\
\text { Local disease: } \\
\text { 25-36 Gy (median dose } 35 \text { Gy) at } \\
\text { primary tumour site } \\
\text { Metastatic disease: } \\
\text { 25-35 Gy at primary tumour site + } \\
\text { 20-25 Gy spinal RT (median dose } 25 \\
\text { Gy) }\end{array}$ & $\begin{array}{l}\text { Median FU }=7 \text { years } \\
10 \text { years EFS }=87.5 \% \\
\text { OS }=100 \%\end{array}$ & $\begin{array}{l}\text { Adjuvant } \\
\text { chemotherapy permits RT dose } \\
\text { reduction and elimination of CSI (in } \\
\text { localised disease) with no significant } \\
\text { differences in OS and EFS }\end{array}$ \\
\hline
\end{tabular}


Table A1. Cont.

\begin{tabular}{|c|c|c|c|c|}
\hline Study & Chemotherapy Regimen \pm Surgery & Radiotherapy & Results & Conclusion \\
\hline $\begin{array}{c}\text { Huh et al. } 1996 \text { [168] } \\
\text { Retrospective study } \\
32 \text { germinomas: } 4 \text { pineal, } 14 \\
\text { suprasellar, } 2 \text { bifocal, } 12 \text { basal } \\
\text { ganglia and thalamus, } \\
\text { including } 3 \text { disseminated cases } \\
\text { Median age = } 14 \text { years } \\
24 \text { males, } 8 \text { females }\end{array}$ & $\begin{array}{l}\text { Surgery: } 1 \text { total resection, } 4 \text { subtotal } \\
\text { resections, } 11 \text { partial resection, } 16 \text { biopsies } \\
\text { No chemotherapy }\end{array}$ & $\begin{array}{l}\text { CSI/WBRT } \pm \text { boost } \\
\text { RT tumour bed } 54 \mathrm{~Gy} \\
\text { Whole-brain } 36 \mathrm{~Gy} \\
\text { Spinal axis } 24 \mathrm{~Gy}\end{array}$ & $\begin{array}{c}\text { Median FU = } 5.1 \text { years } \\
10 \text {-year OS } 97 \% \\
1 \text { death (persistent tumour) } \\
\text { No intracranial or spinal } \\
\text { recurrence }\end{array}$ & $\begin{array}{l}\text { Radiotherapy alone yielded } \\
\text { favourable results }\end{array}$ \\
\hline
\end{tabular}




\section{References}

1. Gittleman, H.; Cioffi, G.; Vecchione-Koval, T.; Ostrom, Q.T.; Kruchko, C.; Osorio, D.S.; Finlay, J.L.; Barnholtz-Sloan, J.S. Descriptive epidemiology of germ cell tumors of the central nervous system diagnosed in the United States from 2006 to 2015 . J. Neuro Oncol. 2019, 143, 251-260. [CrossRef]

2. Schneider, D.T.; Calaminus, G.; Koch, S.; Teske, C.; Schmidt, P.; Haas, R.J.; Harms, D.; Göbel, U. Epidemiologic analysis of 1442 children and adolescents registered in the German germ cell tumor protocols. Pediatr. Blood Cancer 2004, 42, 169-175. [CrossRef]

3. Kurucu, N.; Akyüz, C.; Varan, A.; Zorlu, F.; Aydin, B.; Söylemezoglu, F.; Yalcin, B.; Kutluk, T.; Büyükpamukcus, M. Primary intracranial germ cell tumors in children 36-year experience of a single center. J. Cancer Res. Ther. 2020, 16, 1459-1465. [CrossRef]

4. Takami, H.; Perry, A.; Graffeo, C.S.; Giannini, C.; Narita, Y.; Nakazato, Y.; Saito, N.; Nishikawa, R.; Matsutani, M.; Ichimura, K.; et al. Comparison on epidemiology, tumor location, histology, and prognosis of intracranial germ cell tumors between Mayo Clinic and Japanese consortium cohorts. J. Neurosurg. 2020, 134, 446-456. [CrossRef]

5. Louis, D.N.; Ohgaki, H.; Wiestier, O.D.; Cavenee, W.K. (Eds.) WHO Classification of Tumours of the Central Nervous System, 4th ed.; International Agency for Research on Cancer (IARC): Lyon, France, 2016; pp. 284-287.

6. Matsutani, M.; Sano, K.; Takakura, K.; Fujimaki, T.; Nakamura, O.; Funata, N.; Seto, T. Primary intracranial germ cell tumors: A clinical analysis of 153 histologically verified cases. J. Neurosurg. 1997, 86, 446-455. [CrossRef]

7. Takami, H.; Fukuoka, K.; Fukushima, S.; Nakamura, T.; Mukasa, A.; Saito, N.; Yanagisawa, T.; Nakamura, H.; Sugiyama, K.; Kanamori, M.; et al. Integrated clinical, histopathological, and molecular data analysis of 190 central nervous system germ cell tumors from the iGCT Consortium. Neuro Oncol. 2019, 21, 1565-1577. [CrossRef]

8. Villano, J.L.; Propp, J.M.; Porter, K.R.; Stewart, A.K.; Valyi-Nagy, T.; Li, X.; Engelhard, H.H.; McCarthy, B.J. Malignant pineal germ-cell tumors: An analysis of cases from three tumor registries. Neuro Oncol. 2008, 10, 121-130. [CrossRef] [PubMed]

9. Tso, W.W.-Y.; Yung, A.W.-Y.; Lau, H.-Y.; Chan, G.C.-F. Basal ganglia germinoma: MRI classification correlates well with neurological and cognitive outcome. J. Pediatr. Hematol. Oncol. 2014, 36, e443-e447. [CrossRef] [PubMed]

10. de Pémille, C.V.; Bielle, F.; Mokhtari, K.; Kerboua, E.; Alapetite, C.; Idbaih, A. Basal Ganglia Germinoma in an Adult. World Neurosurg. 2016, 92, 584.e11-584.e14. [CrossRef] [PubMed]

11. Kageyama, H.; Suzuki, T.; Ohara, Y. Intramedullary spinal cord germinoma clinically mimicking multiple sclerosis: A case report. Surg. Neurol. Int. 2019, 10, 201. [CrossRef] [PubMed]

12. Utsuki, S.; Oka, H.; Tanizaki, Y.; Kondo, K.; Fujii, K. Radiological features of germinoma arising from atypical locations. Neurol. Med. Chir. 2005, 45, 268-271. [CrossRef] [PubMed]

13. Shankar, S.; Wu, X.; Kalra, V.B.; Huttner, A.J.; Malhotra, A. Ectopic intracranial germinoma. J. Clin. Neurosci. 2016, 31, 192-195. [CrossRef] [PubMed]

14. Schulte, S.L.; Waha, A.; Steiger, B.; Denkhaus, D.; Dörner, E.; Calaminus, G.; Leuschner, I.; Pietsch, T. CNS germinomas are characterized by global demethylation, chromosomal instability and mutational activation of the Kit-, Ras/Raf/Erk- and Akt-pathways. Oncotarget 2016, 7, 55026-55042. [CrossRef] [PubMed]

15. Sano, M.; Jinguji, S.; Yoshimura, J.; Okamoto, K.; Fujii, Y. De Novo Pineal Region Germinoma in the Seventh Decade of Life: A Case Report. NMC Case Rep. J. 2019, 6, 75-78. [CrossRef]

16. Klopfenstein, J.D.; Lanzino, G.; Kim, L.J.; Spetzler, R.F. Pineal region germinoma in the seventh decade: Case report. Barrow Q. 2002, 18.

17. Bjornsson, J.; Scheithauer, B.W.; Okazaki, H.; Leech, R.W. Intracranial germ cell tumors: Pathobiological and immunohistochemical aspects of 70 cases. J. Neuropathol. Exp. Neurol. 1985, 44, 32-46. [CrossRef] [PubMed]

18. Ho, D.M.; Liu, H.-C. Primary intracranial germ cell tumor. Pathologic study of 51 patients. Cancer 1992, 70, 1577-1584. [CrossRef]

19. Bohara, M.; Hirano, H.; Tokimura, H.; Hanaya, R.; Yonezawa, H.; Campos, F.; Sugiyama, K.; Sugata, S.; Arita, K. Pineal mixed germ cell tumor with a synchronous sellar lesion in the sixth decade. Brain Tumor Pathol. 2011, 28, 163-166. [CrossRef]

20. Saitoh, M.; Tamaki, N.; Kokunai, T.; Matsumoto, S. Clinico-biological behavior of germ-cell tumors. Child's Nerv. Syst. 1991, 7, 246-250. [CrossRef]

21. Merchant, T.E.; Sherwood, S.H.; Mulhern, R.K.; Rose, S.R.; Thompson, S.J.; Sanford, R.A.; Kun, L.E. CNS germinoma: Disease control and long-term functional outcome for 12 children treated with craniospinal irradiation. Int. J. Radiat. Oncol. Biol. Phys. 2000, 46, 1171-1176. [CrossRef]

22. Bamberg, M.; Kortmann, R.-D.; Calaminus, G.; Becker, G.; Meisner, C.; Harms, D.; Göbel, U. Radiation therapy for intracranial germinoma: Results of the German cooperative prospective trials MAKEI 83/86/89. J. Clin. Oncol. 1999, 17, 2585. [CrossRef]

23. Lafay-Cousin, L.; Millar, B.-A.; Mabbott, D.; Spiegler, B.; Drake, J.; Bartels, U.; Huang, A.; Bouffet, E. Limited-field radiation for bifocal germinoma. Int. J. Radiat. Oncol. Biol. Phys. 2006, 65, 486-492. [CrossRef]

24. Sugiyama, K.; Uozumi, T.; Kiya, K.; Mukada, K.; Arita, K.; Kurisu, K.; Hotta, T.; Ogasawara, H.; Sumida, M. Intracranial germ-cell tumor with synchronous lesions in the pineal and suprasellar regions: Report of six cases and review of the literature. Surg. Neurol. 1992, 38, 114-120. [CrossRef]

25. Sawamura, Y.; Ikeda, J.; Shirato, H.; Tada, M.; Abe, H. Germ cell tumours of the central nervous system: Treatment consideration based on 111 cases and their long-term clinical outcomes. Eur. J. Cancer 1998, 34, 104-110. [CrossRef] 
26. Chen, R.; Tao, C.; You, C.; Ju, Y. Fast-developing fatal diffuse leptomeningeal dissemination of a pineal germinoma in a young child: A case report and literature review. Br. J. Neurosurg. 2018. [CrossRef] [PubMed]

27. Hanakita, S.; Takenobu, A.; Kambe, A.; Watanabe, T.; Shin, M.; Teraoka, A. Intramedullary recurrence of germinoma in the spinal cord 15 years after complete remission of a pineal lesion. J. Neurosurg. Spine 2012, 16, 513-515. [CrossRef] [PubMed]

28. Wenger, M.; Lövblad, K.O.; Markwalder, R.; Taub, E. Late recurrence of pineal germinoma. Surg. Neurol. 2002, 57, 34-39. [CrossRef]

29. Takami, H.; Graffeo, C.S.; Perry, A.; Giannini, C.; Daniels, D.J. The Third Eye Sees Double: Cohort Study of Clinical Presentation, Histology, Surgical Approaches, and Ophthalmic Outcomes in Pineal Region Germ Cell Tumors. World Neurosurg. 2021, 150, e482-e490. [CrossRef]

30. Kretschmar, C.S. Germ cell tumors of the brain in children: A review of current literature and new advances in therapy. Cancer Investig. 1997, 15, 187-198. [CrossRef] [PubMed]

31. Inoue, A.; Ohnishi, T.; Kohno, S.; Ohue, S.; Iwata, S.; Matsumoto, S.; Nishikawa, M.; Ozaki, S.; Mizuno, Y.; Kitazawa, R.; et al. Identification of characteristic features of pineal germinoma that enhance accuracy of preoperative differentiation in pineal region tumors: Its significance on optimum surgical treatment. Neurosurg. Rev. 2018, 41, 197-206. [CrossRef]

32. Yang, N.; Zhu, H.-J.; Yao, Y.; He, L.-Y.; Li, Y.-X.; You, H.; Zhang, H.-B. Diabetes insipidus with impaired vision caused by germinoma and perioptic meningeal seeding: A case report. World J. Clin. Cases 2021, 9, 1976-1982. [CrossRef]

33. Oka, H.; Kawano, N.; Tanaka, T.; Utsuki, S.; Kobayashi, I.; Maezawa, H.; Fujii, K. Long-term functional outcome of suprasellar germinomas: Usefulness and limitations of radiotherapy. J. Neuro Oncol. 1998, 40, 185-190. [CrossRef] [PubMed]

34. Reisch, N.; Kühne-Eversmann, L.; Franke, D.; Beuschlein, F.; Mueller-Lisse, U.G.; Reincke, M.; Seissler, J. Intracranial germinoma as a very rare cause of panhypopituitarism in a 23-year old man. Exp. Clin. Endocrinol. Diabetes 2009, 117, 320-323. [CrossRef]

35. Mesquita Filho, P.M.; Santos, F.P.; Köhler, L.R.; Manfroi, G.; De Carli, F.; de Araujo, M.A.; Schwingel, D. Suprasellar Germinomas: 2 Case Reports and Literature Review. World Neurosurg. 2018, 117, 165-171. [CrossRef]

36. Nishio, S.; Inamura, T.; Takeshita, I.; Fukui, M.; Kamikaseda, K. Germ cell tumor in the hypothalamo-neurohypophysial region: Clinical features and treatment. Neurosurg. Rev. 1993, 16, 221-227. [CrossRef]

37. Wellons, J.C., III; Reddy, A.T.; Tubbs, R.S.; Abdullatif, H.; Oakes, W.J.; Blount, J.P.; Grabb, P.A. Neuroendoscopic findings in patients with intracranial germinomas correlating with diabetes insipidus. J. Neurosurg. Pediatr. 2004, 100, 430-436. [CrossRef] [PubMed]

38. Reddy, A.T.; Wellons, J.C., III; Allen, J.C.; Fiveash, J.B.; Abdullatif, H.; Braune, K.W.; Grabb, P.A. Refining the staging evaluation of pineal region germinoma using neuroendoscopy and the presence of preoperative diabetes insipidus. Neuro Oncol. 2004, 6 , 127-133. [CrossRef] [PubMed]

39. Chang, H.-Y.; Chiu, C.-F.; Jung, S.-M.; Wong, A.M.-C.; Wu, C.-T.; Lo, F.-S. Neurological and endocrinological manifestations of 49 children with intracranial pure germinoma at initial diagnosis in Taiwan. Pediatr. Neonatol. 2021, 62, 106-112. [CrossRef] [PubMed]

40. Saeki, N.; Tamaki, K.; Murai, H.; Kubota, M.; Yamaura, A.; Uchida, D.; Noguchi, Y.; Nakamura, S.; Tatsuno, I.; Wada, K.; et al. Long-term outcome of endocrine function in patients with neurohypophyseal germinomas. Endocr. J. 2000, 47, 83-89. [CrossRef]

41. Das, K.K.; Joseph, J.; Singh, A.K.; Sharma, P.; Sardhara, J.; Bhaisora, K.S.; Mehrotra, A.; Srivastava, A.K.; Jaiswal, S.; Sahu, R.N.; et al. Capsuloganglionic Germinoma: A Rare Site for Uncommon Childhood Tumor. Asian J. Neurosurg. 2018, 13, $492-495$. [CrossRef]

42. Goswami, S.; Chakraborty, P.P.; Bhattacharjee, R.; Roy, A.; Thukral, A.; Selvan, C.; Ghosh, S.; Mukhopadhyay, S.; Chowdhury, S. Precocious puberty: A blessing in disguise! Indian J. Endocrinol. Metab. 2013, 17, S111-S113. [CrossRef]

43. Yeo, K.K.; Kayser, K.; Margol, A.S.; Wong, K.K.; Robison, N.; Finlay, J.; Dhall, G. Clinical and neuropsychological outcome of pediatric non-midline central nervous system germinoma treated with chemotherapy and reduced dose/volume irradiation: The Children's Hospital Los Angeles experience. Pediatr. Blood Cancer 2019, 66, e27983. [CrossRef]

44. Huang, Z.-C.; Dong, Q.; Song, E.-P.; Chen, Z.-J.; Zhang, J.-H.; Hou, B.; Lu, Z.-Q.; Qin, F. Germinomas of the basal ganglia and thalamus: Four case reports. World J. Clin. Cases 2020, 8, 4558-4564. [CrossRef] [PubMed]

45. Cohen, D.A.; Bhatti, M.T.; Giannini, C.; Eckel, L.J.; Garrity, J.A.; Chen, J.J. Intracranial Pure Germinoma with Optic Nerve Infiltration. J. Neuro Ophthalmol. 2020, 40, 112-116. [CrossRef] [PubMed]

46. Hayden, J.; Murray, M.J.; Bartels, U.; Ajithkumar, T.; Muthusamy, B.; Penn, A.; Calaminus, G.; Nicholson, J. Symptom interval and treatment burden for patients with malignant central nervous system germ cell tumours. Arch. Dis. Child. 2020, 105, 247-252. [CrossRef]

47. Haase, J.; Nørgaard-Pedersen, B. Alpha-feto-protein (AFP) and human chorionic gonadotropin (HCG) as biochemical markers of intracranial germ-cell tumours. Acta Neurochir. 1979, 50, 67-69. [CrossRef] [PubMed]

48. Arita, N.; Ushio, Y.; Hayakawa, T.; Uozumi, T.; Watanabe, M.; Mori, T.; Mogami, H. Serum levels of alpha-fetoprotein, human chorionic gonadotropin and carcinoembryonic antigen in patients with primary intracranial germ cell tumors. Oncodev. Biol. Med. 1980, 1, 235-240.

49. Utsuki, S.; Oka, H.; Tanaka, S.; Tanizaki, Y.; Fujii, K. Long-term outcome of intracranial germinoma with hCG elevation in cerebrospinal fluid but not in serum. Acta Neurochir. 2002, 144, 1151-1155. [CrossRef]

50. Utsuki, S.; Kawano, N.; Oka, H.; Tanaka, T.; Suwa, T.; Fujii, K. Cerebral germinoma with syncytiotrophoblastic giant cells: Feasibility of predicting prognosis using the serum hCG level. Acta Neurochir. 1999, 141, 975-978. [CrossRef] 
51. Srinivasan, N.; Pakala, A.; Mukkamalla, C.; Oswal, A. Pineal germinoma. South. Med. J. 2010, 103, 1031-1037. [CrossRef]

52. Takami, H.; Perry, A.; Graffeo, C.S.; Giannini, C.; Daniels, D.J. Novel Diagnostic Methods and Posttreatment Clinical Phenotypes Among Intracranial Germ Cell Tumors. Neurosurgery 2020, 87, 563-572. [CrossRef]

53. Carr, C.; O’Neill, B.E.; Hochhalter, C.B.; Strong, M.J.; Ware, M.L. Biomarkers of Pineal Region Tumors: A Review. Ochsner J. 2019, 19, 26-31. [CrossRef] [PubMed]

54. Aihara, Y.; Watanabe, S.; Amano, K.; Komatsu, K.; Chiba, K.; Imanaka, K.; Hori, T.; Ohba, T.; Dairoku, H.; Okada, Y.; et al. Placental alkaline phosphatase levels in cerebrospinal fluid can have a decisive role in the differential diagnosis of intracranial germ cell tumors. J. Neurosurg. 2018, 131, 687-694. [CrossRef] [PubMed]

55. Chiba, K.; Aihara, Y.; Komori, T.; Kawamata, T. Placental alkaline phosphatase in cerebrospinal fluid as a biomarker for optimizing surgical treatment strategies for pineal region germ cell tumors. Brain Tumor Pathol. 2020, 37, 60-68. [CrossRef] [PubMed]

56. Morana, G.; Alves, C.A.; Tortora, D.; Finlay, J.L.; Severino, M.; Nozza, P.; Ravegnani, M.; Pavanello, M.; Milanaccio, C.; Maghnie, M.; et al. T2*-based MR imaging (gradient echo or susceptibility-weighted imaging) in midline and off-midline intracranial germ cell tumors: A pilot study. Neuroradiology 2018, 60, 89-99. [CrossRef]

57. Awa, R.; Campos, F.; Arita, K.; Sugiyama, K.; Tominaga, A.; Kurisu, K.; Yamasaki, F.; Karki, P.; Tokimura, H.; Fukukura, Y.; et al. Neuroimaging diagnosis of pineal region tumors-quest for pathognomonic finding of germinoma. Neuroradiology 2014, 56, 525-534. [CrossRef]

58. Chavhan, G.B.; Babyn, P.S.; Thomas, B.; Shroff, M.M.; Haacke, E.M. Principles, techniques, and applications of T2*-based MR imaging and its special applications. Radiographics 2009, 29, 1433-1449. [CrossRef] [PubMed]

59. Takano, M.; Kinoshita, Y.; Sugiyama, K.; Kolakshyapati, M.; Takayasu, T.; Yonezawa, U.; Taguchi, A.; Akiyama, Y.; Amatya, V.J.; Takeshima, Y.; et al. Detecting non-germinomatous germ cell tumor component by arterial spin labeling perfusion-weighted MR imaging in central nervous system germ cell tumor. Eur. J. Radiol. 2021, 136, 109523. [CrossRef] [PubMed]

60. Esfahani, D.R.; Alden, T.; DiPatri, A.; Xi, G.; Goldman, S.; Tomita, T. Pediatric Suprasellar Germ Cell Tumors: A Clinical and Radiographic Review of Solitary vs. Bifocal Tumors and Its Therapeutic Implications. Cancers 2020, 12, 2621. [CrossRef]

61. Mootha, S.L.; Barkovich, A.J.; Grumbach, M.M.; Edwards, M.S.; Gitelman, S.E.; Kaplan, S.L.; Conte, F.A. Idiopathic hypothalamic diabetes insipidus, pituitary stalk thickening, and the occult intracranial germinoma in children and adolescents. J. Clin. Endocrinol. Metab. 1997, 82, 1362-1367. [CrossRef]

62. Devuyst, F.; Kazakou, P.; Baleriaux, D.; Alexopoulou, O.; Burniat, A.; Salenave, S.; Chanson, P.; Corvilain, B.; Maiter, D. Central diabetes insipidus and pituitary stalk thickening in adults: Distinction of neoplastic from non-neoplastic lesions. Eur. J. Endocrinol. 2020, 183, 95-105. [CrossRef] [PubMed]

63. Ram, N.; Batool, S.; Mushtaq, N. A Case Report Emphasizing the Importance of Early Diagnosis and Management of Intracranial Germinoma. Cureus 2020, 12, e11721. [CrossRef] [PubMed]

64. Dias, D.; Vilar, H.; Passos, J.; Leite, V. Central diabetes insipidus caused by a pituitary stalk germinoma resembling infundibuloneurohypophysitis. BMJ Case Rep. 2020, 13, e234724. [CrossRef]

65. Bóssolo, A.G.; Garcia, M.M.; Davila, K.; Brau, R.; Ortiz, J.S.; Martinez, J.H. A Rare Localized Pituitary Stalk Germinoma Presenting in the Third Decade. Case Rep. Endocrinol. 2018, 2018, 1746917. [CrossRef]

66. Zhou, X.; Zhu, H.; Yao, Y.; Lian, X.; Feng, F.; Wang, L.; Liu, S.; Deng, K.; You, H.; Yang, H.; et al. Etiological Spectrum and Pattern of Change in Pituitary Stalk Thickening: Experience in 321 Patients. J. Clin. Endocrinol. Metab. 2019, 104, 3419-3427. [CrossRef]

67. Wu, C.-C.; Guo, W.-Y.; Chang, F.-C.; Luo, C.-B.; Lee, H.-J.; Chen, Y.-W.; Lee, Y.-Y.; Wong, T.-T. MRI features of pediatric intracranial germ cell tumor subtypes. J. Neuro Oncol. 2017, 134, 221-230. [CrossRef]

68. Balossier, A.; Blond, S.; Reyns, N. Endoscopic Versus Stereotactic Procedure for Pineal Tumor Biopsies: Focus on Overall Efficacy Rate. World Neurosurg. 2016, 92, 223-228. [CrossRef]

69. Kanamori, M.; Takami, H.; Yamaguchi, S.; Sasayama, T.; Yoshimoto, K.; Tominaga, T.; Inoue, A.; Ikeda, N.; Kambe, A.; Kumabe, T.; et al. So-called bifocal tumors with diabetes insipidus and negative tumor markers: Are they all germinoma? Neuro Oncol. 2020, 23, 295-303. [CrossRef] [PubMed]

70. Day, E.L.; Smith, E.R.; Fehnel, K.P. Single-institution case series of pituitary biopsy for suspected germinoma in the pediatric population: Diagnostic utility, operative risks, and biopsy approaches. Sci. Rep. 2020, 10, 15257. [CrossRef]

71. Liu, W.; Raynald; Tian, Y.; Gong, J.; Ma, Z.; Ma'ruf, L.; Li, C. Simultaneous single-trajectory endoscopic biopsy and third ventriculostomy in pediatric pineal region tumors. Acta Neurol. Belg. 2020. [CrossRef]

72. Gao, Y.; Jiang, J.; Liu, Q. Clinicopathological and immunohistochemical features of primary central nervous system germ cell tumors: A 24-years experience. Int. J. Clin. Exp. Pathol. 2014, 7, 6965-6972.

73. Zapka, P.; Dörner, E.; Dreschmann, V.; Sakamato, N.; Kristiansen, G.; Calaminus, G.; Vokuhl, C.; Leuschner, I.; Pietsch, T. Type, Frequency, and Spatial Distribution of Immune Cell Infiltrates in CNS Germinomas: Evidence for Inflammatory and Immunosuppressive Mechanisms. J. Neuropathol. Exp. Neurol. 2018, 77, 119-127. [CrossRef] [PubMed]

74. Cao, D.; Liu, A.; Wang, F.; Allan, R.W.; Mei, K.; Peng, Y.; Du, J.; Guo, S.; Abel, T.W.; Lane, Z.; et al. RNA-binding protein LIN28 is a marker for primary extragonadal germ cell tumors: An immunohistochemical study of 131 cases. Mod. Pathol. 2011, 24, $288-296$. [CrossRef]

75. Pantazis, G.; Harter, P.N.; Capper, D.; Kohlhof, P.; Mittelbronn, M.; Schittenhelm, J. The embryonic stem cell factor UTF1 serves as a reliable diagnostic marker for germinomas. Pathology 2014, 46, 225-229. [CrossRef] 
76. Calaminus, G.; Kortmann, R.; Worch, J.; Nicholson, J.C.; Alapetite, C.; Garrè, M.L.; Patte, C.; Ricardi, U.; Saran, F.; Frappaz, D. SIOP CNS GCT 96: Final report of outcome of a prospective, multinational nonrandomized trial for children and adults with intracranial germinoma, comparing craniospinal irradiation alone with chemotherapy followed by focal primary site irradiation for patients with localized disease. Neuro Oncol. 2013, 15, 788-796. [CrossRef]

77. Allen, J.C. Controversies in the management of intracranial germ cell tumors. Neurol. Clin. 1991, 9, 441-452. [CrossRef]

78. Aoyama, I.; Kondo, A.; Ogawa, H.; Ikai, Y. Germinoma in siblings: Case reports. Surg. Neurol. 1994, 41, 313-317. [CrossRef]

79. Nitta, N.; Fukami, T.; Nozaki, K. Germinoma in two brothers: Case report. Neurol. Med. Chir. 2013, 53, 703-706. [CrossRef]

80. Doknic, M.; Savic, D.; Manojlovic-Gacic, E.; Savo, R.; Bokun, J.; Milenkovic, T.; Pavlovic, S.; Vreca, M.; Andjelkovic, M.; Stojanovic, M.; et al. Clinical case seminar: Familial intracranial germinoma. Endokrynol. Pol. 2018, 69, 612-618. [CrossRef]

81. Shimizu, K.; Mineharu, Y.; Imamura, H.; Asai, K.; Imai, Y.; Ichimura, K.; Sakai, N. Intracranial germinomas in a father and his son. Child's Nerv. Syst. 2014, 30, 2143-2146. [CrossRef] [PubMed]

82. Fukushima, S.; Yamashita, S.; Kobayashi, H.; Takami, H.; Fukuoka, K.; Nakamura, T.; Yamasaki, K.; Matsushita, Y.; Nakamura, H.; Totoki, Y.; et al. Genome-wide methylation profiles in primary intracranial germ cell tumors indicate a primordial germ cell origin for germinomas. Acta Neuropathol. 2017, 133, 445-462. [CrossRef] [PubMed]

83. Amatruda, J.F.; Ross, J.A.; Christensen, B.; Fustino, N.J.; Chen, K.S.; Hooten, A.J.; Nelson, H.; Kuriger, J.K.; Rakheja, D.; Frazier, A.L.; et al. DNA methylation analysis reveals distinct methylation signatures in pediatric germ cell tumors. BMC Cancer 2013, 13, 313. [CrossRef] [PubMed]

84. Nakata, Y.; Yagishita, A.; Arai, N. Two patients with intraspinal germinoma associated with Klinefelter syndrome: Case report and review of the literature. Am. J. Neuroradiol. 2006, 27, 1204-1210. [PubMed]

85. Matsumura, N.; Kurimoto, M.; Endo, S.; Fukuda, O.; Takaku, A. Intracranial germinoma associated with Down's syndrome. Pediatr. Neurosurg. 1998, 29, 199-202. [CrossRef]

86. Fukushima, S.; Otsuka, A.; Suzuki, T.; Yanagisawa, T.; Mishima, K.; Mukasa, A.; Saito, N.; Kumabe, T.; Kanamori, M.; Tominaga, T.; et al. Mutually exclusive mutations of KIT and RAS are associated with KIT mRNA expression and chromosomal instability in primary intracranial pure germinomas. Acta Neuropathol. 2014, 127, 911-925. [CrossRef] [PubMed]

87. Wang, L.; Yamaguchi, S.; Burstein, M.D.; Terashima, K.; Chang, K.; Ng, H.-K.; Nakamura, H.; He, Z.; Doddapaneni, H.; Lewis, L.; et al. Novel somatic and germline mutations in intracranial germ cell tumours. Nature 2014, 511, 241-245. [CrossRef] [PubMed]

88. Ichimura, K.; Fukushima, S.; Totoki, Y.; Matsushita, Y.; Otsuka, A.; Tomiyama, A.; Niwa, T.; Takami, H.; Nakamura, T.; Suzuki, T.; et al. Recurrent neomorphic mutations of MTOR in central nervous system and testicular germ cell tumors may be targeted for therapy. Acta Neuropathol. 2016, 131, 889-901. [CrossRef] [PubMed]

89. Kamakura, Y.; Hasegawa, M.; Minamoto, T.; Yamashita, J.; Fujisawa, H. C-kit gene mutation: Common and widely distributed in intracranial germinomas. J. Neurosurg. Pediatr. 2006, 104, 173-180. [CrossRef]

90. Sakuma, Y.; Sakurai, S.; Oguni, S.; Satoh, M.; Hironaka, M.; Saito, K. c-kit gene mutations in intracranial germinomas. Cancer Sci. 2004, 95, 716-720. [CrossRef]

91. Gao, Y.-P.; Jiang, J.-Y.; Liu, Q. Expression and mutation of c-Kit in intracranial germ cell tumors: A single-centre retrospective study of 30 cases in China. Oncol. Lett. 2016, 11, 2971-2976. [CrossRef]

92. Low, S.Y.Y.; Cheng, H.; Zou, R.; Ng, L.P.; Kuick, C.H.; Sulaiman, N.B.S.; Chang, K.T.E.; Low, D.C.Y.; Zhou, L.; Seow, W.T. Molecular exploration of paediatric intracranial germinomas from multi-ethnic Singapore. BMC Neurol. 2020, 20, 415. [CrossRef]

93. Ventura, M.; Gomes, L.; Rosmaninho-Salgado, J.; Barros, L.; Paiva, I.; Melo, M.; Oliveira, D.; Carrilho, F. Bifocal germinoma in a patient with 16p11.2 microdeletion syndrome. Endocrinol. Diabetes Metab. Case Rep. 2019, 2019. [CrossRef]

94. Wang, H.-W.; Wu, Y.-H.; Hsieh, J.-Y.; Liang, M.-L.; Chao, M.-E.; Liu, D.-J.; Hsu, M.-T.; Wong, T.-T. Pediatric primary central nervous system germ cell tumors of different prognosis groups show characteristic miRNome traits and chromosome copy number variations. BMC Genom. 2010, 11, 132. [CrossRef]

95. Takayasu, T.; Shah, M.; Dono, A.; Yan, Y.; Borkar, R.; Putluri, N.; Zhu, J.-J.; Hama, S.; Yamasaki, F.; Tahara, H.; et al. Cerebrospinal fluid ctDNA and metabolites are informative biomarkers for the evaluation of CNS germ cell tumors. Sci. Rep. 2020, 10, 14326. [CrossRef]

96. Palmer, R.D.; Murray, M.J.; Saini, H.K.; van Dongen, S.; Abreu-Goodger, C.; Muralidhar, B.; Pett, M.R.; Thornton, C.M.; Nicholson, J.C.; Enright, A.J.; et al. Malignant germ cell tumors display common microRNA profiles resulting in global changes in expression of messenger RNA targets. Cancer Res. 2010, 70, 2911-2923. [CrossRef]

97. Murray, M.J.; Ajithkumar, T.; Harris, F.; Williams, R.M.; Jalloh, I.; Cross, J.; Ronghe, M.; Ward, D.; Scarpini, C.G.; Nicholson, J.C.; et al. Clinical utility of circulating miR-371a-3p for the management of patients with intracranial malignant germ cell tumors. Neuro Oncol. Adv. 2020, 2, vdaa048. [CrossRef] [PubMed]

98. ClinicalTrials.gov. Available online: https:/ / clinicaltrials.gov/ct2/show /NCT04435756 (accessed on 14 May 2021).

99. Murray, M.J.; Bell, E.; Raby, K.L.; Rijlaarsdam, M.A.; Gillis, A.J.M.; Looijenga, L.H.J.; Brown, H.; Destenaves, B.; Nicholson, J.C.; Coleman, N. A pipeline to quantify serum and cerebrospinal fluid microRNAs for diagnosis and detection of relapse in paediatric malignant germ-cell tumours. Br. J. Cancer 2016, 114, 151-162. [CrossRef] [PubMed]

100. Lobo, J.; Rodrigues, Â.; Guimarães, R.; Cantante, M.; Lopes, P.; Mauricio, J.; Oliveira, J.; Jeronimo, C.; Henrique, R. Detailed Characterization of Immune Cell Infiltrate and Expression of Immune Checkpoint Molecules PD-L1/CTLA-4 and MMR Proteins in Testicular Germ Cell Tumors Disclose Novel Disease Biomarkers. Cancers 2019, 11, 1535. [CrossRef] 
101. Nishimoto, M.; Ohara, K.; Kamamoto, D.; Tamura, R.; Miwa, T.; Yoshida, K.; Sasaki, H. Tumor immune microenvironment is associated with the growth of intracranial germinomas. J. Neuro Oncol. 2020, 146, 139-146. [CrossRef] [PubMed]

102. Takami, H.; Fukushima, S.; Aoki, K.; Satomi, K.; Narumi, K.; Hama, N.; Matsushita, Y.; Fukuoka, K.; Yamasaki, K.; Nakamura, T.; et al. Intratumoural immune cell landscape in germinoma reveals multipotent lineages and exhibits prognostic significance. Neuropathol. Appl. Neurobiol. 2020, 46, 111-124. [CrossRef]

103. Liu, B.; Arakawa, Y.; Yokogawa, R.; Tokunaga, S.; Terada, Y.; Murata, D.; Matsui, Y.; Fujimoto, K.-I.; Fukui, N.; Tanji, M.; et al. PD-1/PD-L1 expression in a series of intracranial germinoma and its association with Foxp3+ and CD8+ infiltrating lymphocytes. PLoS ONE 2018, 13, e0194594. [CrossRef]

104. Wildeman, M.E.; Shepard, M.J.; Oldfield, E.H.; Lopes, M.B.S. Central Nervous System Germinomas Express Programmed Death Ligand 1. J. Neuropathol. Exp. Neurol. 2018, 77, 312-316. [CrossRef] [PubMed]

105. Maity, A.; Shu, H.-K.; Janss, A.; Belasco, J.B.; Rorke, L.; Phillips, P.C.; Sutton, L.N.; Goldwein, J.W. Craniospinal radiation in the treatment of biopsy-proven intracranial germinomas: Twenty-five years' experience in a single center. Int. J. Radiat. Oncol. Biol. Phys. 2004, 58, 1165-1170. [CrossRef] [PubMed]

106. Bishr, M.K.; Zaghloul, M.S.; Elmaraghi, C.; Galal, A.; Abdelaziz, M.S.; Elghazawy, H.I.; Shaheen, H.; Ramzy, E.S.; Mesbah, A.; Eissa, S.K.; et al. The radiotherapy utilization rate in pediatric tumors: An analysis of 13,305 patients. Radiother. Oncol. 2020, 154, 220-226. [CrossRef]

107. Kellie, S.J.; Boyce, H.; Dunkel, I.J.; Diez, B.; Rosenblum, M.; Brualdi, L.; Finlay, J.L. Intensive cisplatin and cyclophosphamidebased chemotherapy without radiotherapy for intracranial germinomas: Failure of a primary chemotherapy approach. Pediatr. Blood Cancer 2004, 43, 126-133. [CrossRef]

108. Kellie, S.J.; Boyce, H.; Dunkel, I.J.; Diez, B.; Rosenblum, M.; Brualdi, L.; Finlay, J.L. Primary chemotherapy for intracranial nongerminomatous germ cell tumors: Results of the second international CNS germ cell study group protocol. J. Clin. Oncol. 2004, 22, 846-853. [CrossRef] [PubMed]

109. Balmaceda, C.; Heller, G.; Rosenblum, M.; Diez, B.; Villablanca, J.G.; Kellie, S.; Maher, P.; Vlamis, V.; Walker, R.W.; Leibel, S.; et al. Chemotherapy without irradiation-A novel approach for newly diagnosed CNS germ cell tumors: Results of an international cooperative trial. The First International Central Nervous System Germ Cell Tumor Study. J. Clin. Oncol. 1996, 14, $2908-2915$. [CrossRef] [PubMed]

110. Packer, R.J.; Cohen, B.H.; Cooney, K. Intracranial germ cell tumors. Oncologist 2000, 5, 312-320. [CrossRef]

111. Fu, H.; Guo, X.; Li, R.; Xing, B. Radiotherapy and chemotherapy plus radiation in the treatment of patients with pure intracranial germinoma: A meta-analysis. J. Clin. Neurosci. 2017, 43, 32-38. [CrossRef]

112. Bhimani, A.D.; Barrington, N.M.; Aguilar, T.M.; Arnone, G.D.; Mehta, A.I. Pituitary germinomas: A multi-institutional study analyzing patient demographics and management patterns. Pituitary 2020, 23, 381-388. [CrossRef] [PubMed]

113. Murray, M.J.; Metayer, L.E.; Mallucci, C.L.; Hale, J.P.; Nicholson, J.C.; Kirollos, R.W.; Burke, G.A.A. Intra-abdominal metastasis of an intracranial germinoma via ventriculo-peritoneal shunt in a 13-year-old female. Br. J. Neurosurg. 2011, 25, 747-749. [CrossRef]

114. Roth, J.; Constantini, S. Combined rigid and flexible endoscopy for tumors in the posterior third ventricle. J. Neurosurg. 2015, 122, 1341-1346. [CrossRef]

115. Abbassy, M.; Aref, K.; Farhoud, A.; Hekal, A. Outcome of single-trajectory rigid endoscopic third ventriculostomy and biopsy in the management algorithm of pineal region tumors: A case series and review of the literature. Child's Nerv. Syst. 2018, 34, 1335-1344. [CrossRef]

116. Shahrestani, S.; Ravi, V.; Strickland, B.; Rutkowski, M.; Zada, G. Pure Endoscopic Supracerebellar Infratentorial Approach to the Pineal Region: A Case Series. World Neurosurg. 2020, 137, e603-e609. [CrossRef] [PubMed]

117. Gu, Y.; Zhou, Q.; Zhu, W.; Wu, Q.; Xie, T.; Wu, S.; Hu, F.; Yu, Y.; Sun, C.; Li, C.; et al. The Purely Endoscopic Supracerebellar Infratentorial Approach for Resecting Pineal Region Tumors with Preservation of Cerebellomesencephalic Vein: Technical Note and Preliminary Clinical Outcomes. World Neurosurg. 2019, 128, e334-e339. [CrossRef]

118. Aoyama, H.; Shirato, H.; Ikeda, J.; Fujieda, K.; Miyasaka, K.; Sawamura, Y. Induction chemotherapy followed by low-dose involved-field radiotherapy for intracranial germ cell tumors. J. Clin. Oncol. 2002, 20, 857-865. [CrossRef] [PubMed]

119. Shimizu, H.; Motomura, K.; Ohka, F.; Aoki, K.; Tanahashi, K.; Hirano, M.; Chalise, L.; Nishikawa, T.; Yamaguchi, J.; Yoshida, J.; et al. Long-term survival in patients with primary intracranial germ cell tumors treated with surgery, platinum-based chemotherapy, and radiotherapy: A single-institution study. J. Neurosurg. 2020. [CrossRef] [PubMed]

120. Alapetite, C.; Brisse, H.; Patte, C.; Raquin, M.A.; Gaboriaud, G.; Carrie, C.; Habrand, J.L.; Thiesse, P.; Cuilliere, J.C.; Bernier, V.; et al. Pattern of relapse and outcome of non-metastatic germinoma patients treated with chemotherapy and limited field radiation: The SFOP experience. Neuro Oncol. 2010, 12, 1318-1325. [CrossRef] [PubMed]

121. Zhang, H.; Qi, S.-T.; Fan, J.; Fang, L.-X.; Qiu, B.-H.; Liu, Y.; Qiu, X.-Y. Bifocal germinomas in the pineal region and hypothalamoneurohypophyseal axis: Primary or metastasis? J. Clin. Neurosci. 2016, 34, 151-157. [CrossRef]

122. Shibamoto, Y.; Sasai, K.; Oya, N.; Hiraoka, M. Intracranial germinoma: Radiation therapy with tumor volume-based dose selection. Radiology 2001, 218, 452-456. [CrossRef]

123. Rogers, S.J.; Mosleh-Shirazi, M.A.; Saran, F.H. Radiotherapy of localised intracranial germinoma: Time to sever historical ties? Lancet Oncol. 2005, 6, 509-519. [CrossRef] 
124. Lee, D.S.; Lim, D.H.; Kim, I.H.; Kim, J.-Y.; Han, J.W.; Yoo, K.H.; Park, K.D.; Park, H.J.; Chung, N.-G.; Suh, C.-O.; et al. Upfront chemotherapy followed by response adaptive radiotherapy for intracranial germinoma: Prospective multicenter cohort study. Radiother. Oncol. 2019, 138, 180-186. [CrossRef] [PubMed]

125. Jennings, M.T.; Gelman, R.; Hochberg, F. Intracranial germ-cell tumors: Natural history and pathogenesis. J. Neurosurg. 1985, 63, 155-167. [CrossRef] [PubMed]

126. Park, J.; Park, Y.; Lee, S.U.; Kim, T.; Choi, Y.-K.; Kim, J.-Y. Differential dosimetric benefit of proton beam therapy over intensity modulated radiotherapy for a variety of targets in patients with intracranial germ cell tumors. Radiat. Oncol. 2015, 10, 135. [CrossRef] [PubMed]

127. Kretschmar, C.; Kleinberg, L.; Greenberg, M.; Burger, P.; Holmes, E.; Wharam, M. Pre-radiation chemotherapy with responsebased radiation therapy in children with central nervous system germ cell tumors: A report from the Children's Oncology Group. Pediatr. Blood Cancer 2007, 48, 285-291. [CrossRef]

128. Matsutani, M.; The Japanese Pediatric Brain Tumor Study Group. Combined chemotherapy and radiation therapy for CNS germ cell tumors-The Japanese experience. J. Neuro Oncol. 2001, 54, 311-316. [CrossRef]

129. Bouffet, E.; Baranzelli, M.C.; Patte, C.; Portas, M.; Edan, C.; Chastagner, P.; Mechinaud-Lacroix, F.; Kalifa, C. Combined treatment modality for intracranial germinomas: Results of a multicentre SFOP experience. Br. J. Cancer 1999, 79, 1199-1204. [CrossRef]

130. Sawamura, Y.; Shirato, H.; Ikeda, J.; Tada, M.; Ishii, N.; Kato, T.; Abe, H.; Fujieda, K. Induction chemotherapy followed by reduced-volume radiation therapy for newly diagnosed central nervous system germinoma. J. Neurosurg. 1998, 88, 66-72. [CrossRef]

131. Toll, S.A.; Jones, M.T.; Yoshida, E.J.; Dhall, G.; Olch, A.J.; Wong, K.K. The relationship between ventricular volume and whole-brain irradiation dose in central nervous system germ cell tumors. Pediatr. Blood Cancer 2019, 66, e28005. [CrossRef]

132. Iorio-Morin, C.; Kano, H.; Huang, M.; Lunsford, L.D.; Simonová, G.; Liscak, R.; Cohen-Inbar, O.; Sheehan, J.; Lee, C.-C.; Wu, H.-M.; et al. Histology-Stratified Tumor Control and Patient Survival After Stereotactic Radiosurgery for Pineal Region Tumors: A Report From the International Gamma Knife Research Foundation. World Neurosurg. 2017, 107, 974-982. [CrossRef]

133. Spiegler, B.J.; Bouffet, E.; Greenberg, M.L.; Rutka, J.T.; Mabbott, D.J. Change in neurocognitive functioning after treatment with cranial radiation in childhood. J. Clin. Oncol. 2004, 22, 706-713. [CrossRef]

134. Padovani, L.; André, N.; Constine, L.S.; Muracciole, X. Neurocognitive function after radiotherapy for paediatric brain tumours. Nat. Rev. Neurol. 2012, 8, 578-588. [CrossRef] [PubMed]

135. Mulhern, R.K.; Merchant, T.E.; Gajjar, A.; Reddick, W.E.; Kun, L.E. Late neurocognitive sequelae in survivors of brain tumours in childhood. Lancet Oncol. 2004, 5, 399-408. [CrossRef]

136. Yang, J.C.; Terezakis, S.A.; Dunkel, I.J.; Gilheeney, S.W.; Wolden, S.L. Intensity-Modulated Radiation Therapy with Dose Painting: A Brain-Sparing Technique for Intracranial Germ Cell Tumors. Pediatr. Blood Cancer 2016, 63, 646-651. [CrossRef]

137. Phi, J.H.; Cho, B.-K.; Kim, S.-K.; Paeng, J.C.; Kim, I.-O.; Kim, I.H.; Kim, D.G.; Jung, H.-W.; Kim, J.E.; Wang, K.-C. Germinomas in the basal ganglia: Magnetic resonance imaging classification and the prognosis. J. Neuro Oncol. 2010, 99, 227-236. [CrossRef] [PubMed]

138. Cheng, S.; Kilday, J.-P.; Laperriere, N.; Janzen, L.; Drake, J.; Bouffet, E.; Bartels, U. Outcomes of children with central nervous system germinoma treated with multi-agent chemotherapy followed by reduced radiation. J. Neuro Oncol. 2016, 127, 173-180. [CrossRef] [PubMed]

139. Shikama, N.; Ogawa, K.; Tanaka, S.; Toita, T.; Nakamura, K.; Uno, T.; Ohnishi, H.; Itami, J.; Tada, T.; Saeki, N. Lack of benefit of spinal irradiation in the primary treatment of intracranial germinoma: A multiinstitutional, retrospective review of 180 patients. Cancer 2005, 104, 126-134. [CrossRef] [PubMed]

140. Wong, J.; Goddard, K.; Laperriere, N.; Dang, J.; Bouffet, E.; Bartels, U.; Hodgson, D.; Tyldesley, S.; Hukin, J.; Cheng, S.; et al. Long term toxicity of intracranial germ cell tumor treatment in adolescents and young adults. J. Neuro Oncol. 2020, 149, 523-532. [CrossRef]

141. Xiang, B.; Zhu, X.; He, M.; Wu, W.; Pang, H.; Zhang, Z.; Yang, Y.; Li, Y.; Wang, Y.; Wang, Y.; et al. Pituitary Dysfunction in Patients with Intracranial Germ Cell Tumors Treated with Radiotherapy. Endocr. Pract. 2020, 26, 1458-1468. [CrossRef]

142. Kumanogoh, A.; Kasayama, S.; Kouhara, H.; Koga, M.; Arita, N.; Hayakawa, T.; Kishimoto, T.; Sato, B. Effects of therapy on anterior pituitary functions in patients with primary intracranial germ cell tumor. Endocr. J. 1994, 41, 287-292. [CrossRef]

143. Ueba, T.; Yamashita, K.; Fujisawa, I.; Nakao, S.; Ooyama, K.; Yorihuji, T.; Kato, S.F.; Seto, S.; Kageyama, N. Long-term follow-up of 5 patients with intracranial germinoma initially treated by chemotherapy alone. Acta Neurochir. 2007, 149, 897-902. [CrossRef] [PubMed]

144. Nam, D.-H.; Wang, K.-C.; Shin, C.-H.; Yang, S.-W.; Cho, B.-K. A simple method of predicting hormonal outcome in children with intracranial germinoma. Child's Nerv. Syst. 1999, 15, 179-184. [CrossRef]

145. Matsuo, A.; Kawahara, I.; Moritsuka, T.; Honda, K.; Ito, T.; Haraguchi, W.; Hiu, T.; Ono, T.; Ushijima, R.; Tsutsumi, K. A Case of Radiation-induced Glioblastoma 29 Years after Treatments for Germinoma. No Shinkei Geka 2020, 48, 793-799. [CrossRef] [PubMed]

146. Hong, K.T.; Lee, D.H.; Kim, B.K.; An, H.Y.; Choi, J.Y.; Phi, J.H.; Cheon, J.-E.; Kang, H.J.; Kim, S.-K.; Kim, J.-Y.; et al. Treatment outcome and long-term follow-up of central nervous system germ cell tumor using upfront chemotherapy with subsequent photon or proton radiation therapy: A single tertiary center experience of 127 patients. BMC Cancer 2020, 20, 979. [CrossRef] [PubMed] 
147. Li, B.; Feng, J.; Chen, L.; Li, Y.; Wang, J.; Lv, W.; Li, Y.; Liu, Y.; Liu, S.; Luo, S.; et al. Relapse pattern and quality of life in patients with localized basal ganglia germinoma receiving focal radiotherapy, whole-brain radiotherapy, or craniospinal irradiation. Radiother. Oncol. 2021, 158, 90-96. [CrossRef] [PubMed]

148. Baroni, L.V.; Oller, A.; Freytes, C.S.; Sampor, C.V.; Pinto, N.; Fernandez, N.P.; Rugilo, C.; Lubieniecki, F.; Zubizarreta, P.; Alderete, D. Intracranial germ cells tumour: A single institution experience in Argentina. J. Neuro Oncol. 2021, 152, 363-372. [CrossRef]

149. Kumar, N.; Madan, R.; Dracham, C.B.; Khosla, D.; Das, N.; Dey, T.; Elangovan, A.; Tripathi, M.; Gupta, K.; Ahuja, C.K.; et al. Multimodality treatment for Central Nervous System Germ Cell Tumors: Disease spectrum and management strategies-A tertiary care center experience from India. Clin. Neurol. Neurosurg. 2021, 202, 106481. [CrossRef]

150. Kelly, C.M.; Sainz, L.G.; Chi, P. The management of metastatic GIST: Current standard and investigational therapeutics. J. Hematol. Oncol. 2021, 14, 2. [CrossRef]

151. Zalcberg, J.R. Ripretinib for the treatment of advanced gastrointestinal stromal tumor. Ther. Adv. Gastroenterol. 2021, 14. [CrossRef]

152. Osorio, D.S.; Finlay, J.L.; Dhall, G.; Goldman, S.; Eisenstat, D.; Brown, R.J. Feasibility of dasatinib in children and adolescents with new or recurrent central nervous system germinoma. Pediatr. Blood Cancer 2013, 60, E100-E102. [CrossRef]

153. Dasatinib, Ifosfamide, Carboplatin, and Etoposide in Treating Young Patients with Metastatic or Recurrent Malignant Solid Tumors. Available online: https:/ / clinicaltrials.gov/ct2/show/record/NCT00788125 (accessed on 14 May 2021).

154. Zschäbitz, S.; Lasitschka, F.; Hadaschik, B.; Hofheinz, R.-D.; Jentsch-Ullrich, K.; Grüner, M.; Jäger, D.; Grüllich, C. Response to anti-programmed cell death protein-1 antibodies in men treated for platinum refractory germ cell cancer relapsed after high-dose chemotherapy and stem cell transplantation. Eur. J. Cancer 2017, 76, 1-7. [CrossRef]

155. ClinicalTrials.gov. Available online: https:// clinicaltrials.gov/ct2/show/NCT03158064 (accessed on 14 May 2021).

156. Lee, J.H.; Eom, K.-Y.; Phi, J.H.; Park, C.-K.; Kim, S.K.; Cho, B.-K.; Kim, T.M.; Heo, D.S.; Hong, K.T.; Choi, J.Y.; et al. Long-Term Outcomes and Sequelae Analysis of Intracranial Germinoma: Need to Reduce the Extended-Field Radiotherapy Volume and Dose to Minimize Late Sequelae. Cancer Res. Treat. 2021. [CrossRef]

157. Nosrati, J.; Olch, A.J.; Abel, R.J.; Wong, K. Neoadjuvant Chemotherapy and Whole Ventricular Irradiation for Pure Intracranial Germinoma: A Comparison of Three Brain-Sparing Techniques. Cureus 2021, 13, e13670. [CrossRef]

158. Rajagopal, R.; Leong, S.H.; Jawin, V.; Foo, J.C.; Ahmad Bahuri, N.F.; Mun, K.S.; Azman, R.R.; Loh, J.; Yap, T.Y.; Ariffin, H.; et al. Challenges in the Management of Childhood Intracranial Germ Cell Tumors in Middle-Income Countries: A 20-Year Retrospective Review From a Single Tertiary Center in Malaysia. J. Pediatr. Hematol. Oncol. 2021. [CrossRef] [PubMed]

159. Chou, Y.-C.; Wu, Y.-Y.; Hung, S.-P.; Tsang, N.-M.; Pai, P.-C.; Jaing, T.-H.; Lin, C.-Y.; Hsieh, C.-E.; Fan, K.-H.; Kao, W.-H.; et al. Treatment of Primary Central Nervous System Germinomas With Short-course Induction Chemotherapy Followed by Low-dose Radiotherapy Without a Tumor Bed Boost: Prognostic Impact of Human Chorionic Gonadotropin. J. Pediatr. Hematol. Oncol. 2020. [CrossRef] [PubMed]

160. Li, B.; Lv, W.; Li, C.; Yang, J.; Chen, J.; Feng, J.; Chen, L.; Ma, Z.; Li, Y.; Wang, J.; et al. Comparison between Craniospinal Irradiation and Limited-Field Radiation in Patients with Non-metastatic Bifocal Germinoma. Cancer Res. Treat. 2020, 52, 1050-1058. [CrossRef]

161. Takada, A.; Ii, N.; Hirayama, M.; Toyoda, H.; Matsubara, T.; Toyomasu, Y.; Kawamura, T.; Daimon, T.; Sakuma, H.; Nomoto, Y. Long-term follow-up of intensive chemotherapy followed by reduced-dose and reduced-field irradiation for intracranial germ cell tumor. J. Neurosurg. Pediatr. 2018, 23, 317-324. [CrossRef]

162. Weksberg, D.C.; Shibamoto, Y.; Paulino, A.C. Bifocal intracranial germinoma: A retrospective analysis of treatment outcomes in 20 patients and review of the literature. Int. J. Radiat. Oncol. Biol. Phys. 2012, 82, 1341-1351. [CrossRef] [PubMed]

163. MacDonald, S.M.; Trofimov, A.; Safai, S.; Adams, J.; Fullerton, B.; Ebb, D.; Tarbell, N.J.; Yock, T.I. Proton radiotherapy for pediatric central nervous system germ cell tumors: Early clinical outcomes. Int. J. Radiat. Oncol. Biol. Phys. 2011, 79, 121-129. [CrossRef]

164. Eom, K.-Y.; Kim, I.H.; Park, C.I.; Kim, H.J.; Kim, J.H.; Kim, K.; Kim, S.K.; Wang, K.-C.; Cho, B.-G.; Jung, H.-W.; et al. Upfront chemotherapy and involved-field radiotherapy results in more relapses than extended radiotherapy for intracranial germinomas: Modification in radiotherapy volume might be needed. Int. J. Radiat. Oncol. Biol. Phys. 2008, 71, 667-671. [CrossRef] [PubMed]

165. Modak, S.; Gardner, S.; Dunkel, I.J.; Balmaceda, C.; Rosenblum, M.K.; Miller, D.C.; Halpern, S.; Finlay, J.L. Thiotepa-based high-dose chemotherapy with autologous stem-cell rescue in patients with recurrent or progressive CNS germ cell tumors. J. Clin. Oncol. 2004, 22, 1934-1943. [CrossRef] [PubMed]

166. Haas-Kogan, D.A.; Missett, B.T.; Wara, W.M.; Donaldson, S.S.; Lamborn, K.R.; Prados, M.D.; Fisher, P.G.; Huhn, S.L.; Fisch, B.M.; Berger, M.S.; et al. Radiation therapy for intracranial germ cell tumors. Int. J. Radiat. Oncol. Biol. Phys. 2003, 56, 511-518. [CrossRef]

167. Fouladi, M.; Grant, R.; Baruchel, S.; Chan, H.; Malkin, D.; Weitzman, S.; Greenberg, M.L. Comparison of survival outcomes in patients with intracranial germinomas treated with radiation alone versus reduced-dose radiation and chemotherapy. Child's Nerv. Syst. 1998, 14, 596-601. [CrossRef] [PubMed]

168. Huh, S.J.; Shin, K.H.; Kim, I.M.; Ahn, Y.C.; Ha, S.W.; Park, C.I. Radiotherapy of intracranial germinomas. Radiother. Oncol. 1996, 38, 19-23. [CrossRef] 